\title{
The Background of the Western Legal Tradition in the Folklaw of the Peoples of Europe
}

\author{
Harold J. Berman $\dagger$
}

There was a time, prior to the late eleventh century, when the peoples of Western Europe were not conscious of any clear distinction between legal institutions and other institutions of social cohesion such as religion or government or general custom. There were no persons set aside to be lawyers or judges. There were no law schools and no professional legal literature. Popular assemblies issued judgments and kings occasionally proclaimed laws, but these judgments and laws were not consciously systematized. Both in the secular and the ecclesiastical spheres (and at that time the two were largely intermingled with each other), law was primarily local rather than centralized and primarily unwritten rather than enacted. It was primarily folklaw. In the eighth and ninth centuries there developed alongside the folklaw a rudimentary official law of kings and emperors, but it, too, became interwoven with folklaw and embedded in the total social structure.

In the late eleventh and twelfth centuries all this changed "with marvellous suddenness," to use Maitland's phrase..$^{1}$ In every country of the West there were created professional courts, a body of legislation, a legal profession, a legal literature, a "science of law."2 The primary impulse for this development came from the assertion of papal supremacy over the entire Western Church and of the independence of the Church from secular control. This was a Revolution, declared in 1075 by Pope Gregory VII; the papal party and the imperial party fought it out in bloody wars for almost fifty years, and it was only after almost one hundred years, in 1170 , that the martyrdom of Thomas Becket sealed the papal victory in England. ${ }^{3}$

1978 by Harold J. Berman.

$\dagger$ James Barr Ames Professor of Law, Harvard University. This article is adapted from the first chapter of a large work in progress, tentatively entitled THE Western LEGAL Tradition-Its Relation to the Great Revolutions of Western History and to the World RevoLUTION OF THE 20TH CENTURY. For an explanation of the scope of the entire work, see Berman, The Origins of Western Legal Science, 90 Harv. L. Rev. 894 n.*(1977); Berman, The Religious Foundations of Western Law, 24 CATH. U.L. REv. 490 (1975); Berman, The Crisis of the Western Legal Tradition, 9 CREIGHTON L. REv. 252 (1975).

' 2 F. Pollock \& F. Maitland, The History of English Law 458 (2d ed. 1898).

2 See Berman, The Origins of Western Legal Science, 90 Harv. L. REv. 894 (1977).

${ }^{3}$ For discussion of the characterization of the Papal Revolution as a fundamental break in the historical continuity of the Church and as the first of the Great Revolutions of Western history, see Berman, supra note 2, at 897 n.4. 
In the course of the following centuries, the folklaw of the peoples of Europe seemed to disappear almost completely. New sophisticated legal systems were constructed, first for the Church and then for the secular political orders-canon law, urban law, royal law, mercantile law, feudal and manorial law. Eventually, in the period from the sixteenth to the twentieth centuries, a series of Great Revolutions-the German Reformation, the English Revolution, the French and American Revolutions, the Russian Revolution-transformed the Western legal tradition, leaving its Germanic "background" farther and farther behind."

Nevertheless, Western concepts of law-and perhaps more important, Western attitudes toward law-cannot be understood unless they are seen partly in terms of what they first emerged from and reacted against. Especially in the last part of the twentieth century, when Western Man is less sure of his legal tradition than ever before, it is important to recall what it replaced. Surely if new ways are being sought to overcome or supplement Western "legalism," they should be considered in the light of the Germanic alternative which, although it was once rejected, still remains beneath the surface of our historical memory.

\section{Customary European Legal Orders}

The earliest known legal orders prevailing among the peoples of northern and western Europe were mainly tribal in character. Every tribe or "stem" (Stamm) had its own law-the Franks, Burgundians, Visigoths, Ostrogoths, Lombards, Alamans, Bavarians, Frisians, Thuringians, East Saxons, and other peoples that were eventually combined in the Frankish Empire, embracing much of what later became Germany, France, and northern Italy; the Angles, West Saxons, Jutes, Celts, Britons, and other peoples of what later became England; the Danes, Norwegians, Finns, and other Norsemen of Scandinavia and later of Normandy, Sicily, and elsewhere; and many others, from Picts and Scots to Magyars and Slavs. In the period, roughly, from the sixth to the tenth centuries, the legal orders of all these peoples, though largely independent of each other, were nevertheless remarkably similar. On the one hand, the basic legal unit within the tribe was the household, a community of comradeship and trust based partly on kinship and partly

4 The term "Germanic" (germanisch) is used to refer to the northern European peoples generally, including not only Saxons, Alamans, Bavarians, and other peoples who formed what later was called Deutschland ("Germany"; cf. the French Allemagne), but also AngloSaxons, Franks, Lombards, and others. 
on oaths of mutual protection and service. Violation of the peace of the household by an outsider would lead to retaliation in the form of a blood-feud or else to inter-household or inter-clan negotiations designed to forestall or compose the blood-feud. On the other hand, there were also territorial legal units consisting typically of households grouped in villages, villages grouped in larger units often called hundreds and counties, and hundreds and counties grouped in very loosely organized duchies or kingdoms. In the local territorial communities, the chief instrument of government and law was the public assembly ("moot," "thing") of household elders. Together with kinship and local territorial communities, there were also various kinds of lordship-in that sense, feudal-bonds, often formed by households "commending" themselves to great men for protection. ${ }^{5}$

At the head of the tribes and of the local and feudal communities stood royal and ecclesiastical authorities. In the course of time the larger territorial and religious units represented by these higher authorities became more and more important. Kings continued to be called kings of a people (for example, Rex Francigenorum, "king of the Franks"; Rex Anglorum, "king of the Angles") until the twelfth century, but for some centuries prior thereto these terms were also used to refer to vaguely defined political territories (such as Francigena and Anglia). The Church, though headed by emperors and kings within their respective domains, was also recognized as a wider community that transcended secular boundaries. Nevertheless, in the period we are now considering, prior to the latter half of the eleventh century, royal and ecclesiastical authorities did not attempt to alter in any fundamental way the essentially tribal and local and feudal character of the legal orders of Europe. This may seem less strange to the modern reader if it is added that the economy of Europe at that time was also almost wholly local, consisting chiefly of agriculture and cattle-keeping, with subsidiary hunting. Population was sparse. There were few cities or towns, and virtually none with more than a few thousand inhabitants. Commerce played only a small role. And communications in general were very rudimentary. What is strange from an economic or geopolitical point of view is not the weakness of central royal and ecclesiastical law, but the strength of central royal and ecclesiastical authority.

It was the central royal authority, inspired by ecclesiastical counselors, that was responsible for issuing the written collections (or "codes," as they have come to be called) of tribal and local laws

s See H. Loyn, Anglo-Saxon England and the Norman Conquest 292-314 (1962). 
from which a great deal of our knowledge of the folklaw of that period is derived. It should be stressed that with the final disintegration of the Western Roman Empire in the fifth century, what little there had been of the great fabric of Roman law in the Germanic kingdoms diminished and in many places virtually disappeared. Yet the Church preserved the memory of Roman law as well as of Biblical law, and upon his conversion to Christianity a Germanic tribal leader would typically promulgate a set of laws consisting largely of the customs of his people. The earliest of the surviving leges barbarorum ("laws of the barbarians"), as they are called by historians to distinguish them from leges Romanae, was the law of the Salic Franks, the Lex Salica, issued by the Merovingian king Clovis shortly after his conversion to Christianity in $496 .{ }^{8}$ It starts by listing monetary sanctions to be paid by a defendant to a plaintiff for failure to respond to the plaintiff's summons to appear in the local court. It also lists monetary sanctions to be paid by wrongdoers to injured parties for various kinds of offenses-homicides, assaults, thefts, and others. These are typical provisions of primitive law. One of their principal purposes was to induce the parties to a dispute to submit to a decision of the local assembly (the hundred court) instead of resolving their dispute by vendetta. A second purpose was to provide a basis for negotiations between the household of the victim and that of the offender. Sometimes, however, they had not even that effect. The injured party, in the words of one of the Anglo-Saxon laws, might either "buy off the spear or bear it."

The earliest of the Anglo-Saxon legal compilations was the Laws of Ethelbert, promulgated in about 600 A.D. ${ }^{7}$ Ethelbert, ruler of Kent, had been converted to Christianity by Pope Gregory's emissary, the monk Augustine, in 597. Ethelbert's Laws are remarkable for the extraordinarily detailed schedules of tariffs established for various injuries: so much for the loss of a leg, so much for

- The Salic law may be found in English translation in SELECT Historical Documents of THE MiddLe Ages 176-89 (E. Henderson ed. 1912). The date 496 A.D. is still generally accepted, although recent scholarship has raised some doubts about it. Slightly earlier than Salic Law was the compilation of the Lex Visigothorum by King Euric (reigned 466-484), which survives only in a fragmentary state. Other "laws of the barbarians" include the Laws of Ethelbert, King of Kent, issued in about 600, the Edictus Rathari of the Lombard King Rotharius, issued in 643, and in the mid-eighth century the Lex Ribuaria (of the Ripuerian Franks), the Lex Alamannorum (of the Alamans), and the Lex Baiuvariorum (of the Bavarians). See Laws of the Alamans and Bavarians (T. Rivers ed. \& trans. 1977). At the close of the eighth century, envoys of Charlemagne recorded the laws of the Frisians, the Thuringians, and the Saxons. These and others (Scottish, Welsh and Irish, Norwegian, Icelandic, and Russian) are discussed in A. Diamond, Primitive Law Past and Present 308-12 (1971).

7 The Laws of Ethelbert may be found in English translation in F. ATTENBorough, THE LAwS OF THE EARLIEST ENGLiSH Kings $\S \$ 4-17$ (1922) [hereinafter cited as Laws of Ethelbert]. 
an eye, so much if the victim is a slave, so much if he is a freeman, so much if he is a priest, and so on. The four front teeth were worth six shillings each, the teeth next to them four, the other teeth one; thumbs, thumbnails, forefingers, middlefingers, ring fingers, little fingers, and their respective fingernails were all distinguished and a separate price, called a bot, was set for each. Similar distinctions were made between ears whose hearing is destroyed, ears cut off, ears pierced, and ears lacerated; between bones laid bare, bones damaged, bones broken, skulls broken, shoulders disabled, chins broken, collar bones broken, arms broken, thighs broken, and ribs broken; and between bruises outside the clothing, bruises under the clothing, and bruises that do not show black. ${ }^{8}$ If the act of the defendant caused death, the price to be paid to the kin of the deceased was called wer (or wergeld). Much of the written Germanic (including Frankish and Anglo-Saxon) law was concerned with setting different measures of wergeld for killing different classes of people.

The institution of fixed monetary sanctions payable by the kin of the wrongdoer to the kin of the victim was a prominent feature of the law of all the peoples of Europe prior to the twelfth century, and indeed of every Indo-European people at some stage of its development, including the peoples of India, Israel, Greece, and Rome. It is also an important part of the law of many contemporary primitive societies."

It is, in many respects, a very sensible system. The threat of heavy financial burdens upon the wrongdoer and his kin is probably a more effective deterrent of crime than the threat of capital punishment or corporal mutilation (which is what succeeded pecuniary sanctions in Europe in the twelfth and thirteenth centuries). Such monetary sanctions are at least as effective as the modern sanction of imprisonment and surely less expensive for society. Moreover, in terms of retributive justice, not only is the wrongdoer made to suffer but, in contrast to our more "civilized" penology, the victim is thereby made whole.

Yet the system cannot be satisfactorily explained on utilitarian grounds alone, at least insofar as the Germanic peoples of Europe are concerned. In fact, it was part of a whole ideology, a whole world-view. That world-view helps to explain not only the system's

"Id. $\S \S 34-42,50-53,58-60,65-66$.

- See A. Diamond, supra note 6 , at 228,273 . The relationship of primitive law to the socalled Archaic Law of the Indo-European peoples is discussed in the text and note at note 32 infra. 
sensible features but also those features which may not be so sensible-for example, the marked differentiation of payments for the slaying of persons belonging to different classes, the enormous size of the payments (the normal wergeld under the Laws of Ethelbert-100 shillings-represented, according to Diamond, the value of 100 cows, and a noble's wergeld was 300 shillings), ${ }^{10}$ the liability of kindred for wrongdoing regardless of their fault, and the fixed tariffs for injuries regardless of the actual cost to the victim.

The institution of monetary sanctions for crime, payable by the kindred of the wrongdoer to the kindred of the victim, was, as already indicated, a counterpart of the institution of blood-feud. Functionally, therefore, it is to be judged primarily not by the extent to which it served to deter or to punish or to compensate for crime, but by the extent to which it served to forestall inter-family vendettas and, more particularly, by the extent to which it facilitated negotiation and mediation between hostile families. Ideologically, on the other hand, both the institution of the blood-feud and the institution of monetary compensation as a replacement of the blood-feud are to be explained, in Germanic societies, by the high value placed upon honor as a means of winning glory (lof, praise) in a world dominated by warring gods and by a hostile and arbitrary fate $(w y r d)$. Honor, for Germanic man, meant "getting even"; only by "getting even" could he conquer the forces of darkness that surrounded his life. ${ }^{11}$ The fixed schedules of payments provided a standard for evening accounts.

Lof was gained in taking what others defended, as it was lost when others took what you defended. Therefore bot was, in its origins, essentially punitive and only secondarily compensatory. It was the retribution imposed by one household or kin-group upon another. The challenge to lof was particularly great in cases of homicide, because the dead could never recover their own lost honor; the duty rested entirely with their kinsmen, whose first instinct was to resort to vengeance. Originally, the life or limb of the assailant himself (or of another member of his household) was demanded (in Biblical terms "an eye for an eye, a tooth for a tooth"). Where the offense was caused by a non-human agent such as a beast or a tree the offending agent itself might be required to be forfeited (so-called

10 Id. at 63 .

1 This and the following analysis draws on J. Gordley, Anglo-Saxon Law (1970)(unpublished manuscript in the Harvard Law School library). The terms of the analysis are derived from Anglo-Saxon law but they are almost identical with the terms of the other Germanic legal orders of the time, and remarkably similar to the terms of the earliest Indo-European legal orders. 
noxal surrender). The substitution of fixed rates of payment gave dignity to a settlement short of violence, while not altering the basic raison d'être of the remedy, which was redemption of the honor of the household and the kin.

Bot and wer were thus related to mund, which was the protection extended by the household to persons and groups associated with it, and to frith, which was the peace of the household. The king's mund and frith were like any other man's, only better. The Laws of Ethelbert, for example, provided that the king's mundbyrd (that is, the penalty for violating the king's mund,) shall be fifty shillings and a coerl's (commoner's) mundbyrd shall be six shillings. ${ }^{2}$ Mund was violated, and bot or wer was to be paid, when for example, an outsider slept with a serving-maid of the household or slew someone on the premises of the household. Closely related to bot and wer and mund and frith were three other Germanic legal institutions: the surety (borh), the pledge (wed), and the hostage. ${ }^{13}$ A kinsman might act as a surety for a man who agreed to pay wer but could not pay the full amount at once; or the debtor might give a valuable object in pledge; or he might send a hostage to live and work in the enemy household until the price was paid. All these legal devices reflected both the solidarity of the household and the substitution of tribute for vengeance in inter-household or inter-clan strife.

In addition to the settlement of disputes by blood-feud and by inter-household or inter-clan negotiations, the practice existed among the Germanic peoples from earliest times for public assemblies (moots) to hear and decide disputes. However, jurisdiction in most types of cases depended on consent of the parties. Even if they consented to appear they might not remain throughout, and even if they remained, the moot generally could not compel them to submit to its decision. Thus the procedure of the moot had to assume, and to help create, a sufficient degree of trust between the parties to permit the system to operate, just as the procedure for interhousehold or inter-clan negotiations, with its reliance upon sureties, pledges and hostages, had to assume, and to help create, such a degree of trust. Yet it is clear that both the trial before the assembly and the negotiations between the households or clans were apt to be intensely hostile in character. "The two sides faced each other with implacable hostility, determined to make no concessions and to forgive and forget nothing." 14

12 Laws of Ethelbert, supra note 7, $\S \S 8,15$.

13 See Berger, From Hostage to Contract, 35 IrL. L. Rev. 154, 281 (1940).

II J. Gordley, supra note 11, at 23. 
The polar relationship between vengeance (blood-feud) and pacification (composition of blood-feud) in Germanic folklaw is an example of the intense dialectic of mistrust and trust that exists in many contemporary kinship societies. As Claude Lévi-Strauss has written,

Observers have often been struck by the impossibility for natives of conceiving a neutral relationship, or more exactly, no relationship. We have the feeling-which, moreover, is illusory - that the absence of definite kinship gives rise to such a state in our consciousness. But the supposition that this might be the case in primitive thought does not stand up to examination. Every family relationship defines a certain group of rights and duties, while the lack of family relationship . . . defines enmity. ${ }^{15}$

Lévi-Strauss quotes the following passage from Marcel Mauss:

Throughout a considerable period, and in a large number of societies, men met in a curious frame of mind, with exaggerated fear and an equally exaggerated generosity which appear stupid in no one's eyes but our own. . . . There is either complete trust or complete mistrust. One lays down one's arms, renounces magic, and gives everything away, from casual hospitality to one's daughter or one's property..$^{16}$

In Germanic society, the "trust-mistrust" syndrome was closely related to the overriding belief in an arbitrary Fate. This belief was best reflected in the use of the ordeal as a principal method of legal proof. The two principal types of ordeal were those of fire and water, the former for persons of higher rank, the latter for the common people. Originally, these were invocations of the gods of fire and water, respectively. Those tried by fire had to pass blindfolded and barefooted over hot glowing plowshares, or carry burning irons in their hands, and if their burns healed properly they were exonerated. The ordeal of water was performed either in cold water or in hot water. In cold water, the suspect was adjudged guilty if his body was borne up by the water contrary to the course of nature, showing that the water did not accept him. In hot water, he was adjudged innocent if after putting his bare arms and legs into scalding water he came out unhurt. A later, more subtle ordeal, used chiefly by the

is C. Lévi-Strauss, The Elementary Structures of Kinship 482 (J. Bell, J. Von Sturmer, \& R. Needham trans. 1969).

16 M. Mauss, The Gift: Forms and Functions of Exchange in Archaic Societies 79 (1954). 
clergy, was that of the morsel: an ounce of bread or cheese was eaten, with the adjuration, "Close, O Lord this man's stomach so that he cannot swallow this bread (cheese) if he has sworn unjustly." If he could not swallow or keep down the bread or cheese, he was guilty. Such primitive lie-detectors may have worked quite well. In any event, there was considerable resistance to the abolition of ordeals in the thirteenth century. ${ }^{17}$

The system of trial by ordeal was combined with, and sometimes replaced by, trial by ritual oaths ("compurgation"). First came the foreoaths. For example, a party claiming bot for the theft of cattle would swear:

By the Lord, before whom this relic is holy, so I my suit prosecute with full folkright, without fraud and without deceit, and without any guile, as was stolen from me the cattle [designating them] that I claim, and that I have attached with [the defendant].

The opposing party would then swear a denial of this claim. For example:

By the Lord, I was not at rede nor at deed, neither counselor nor doer, where were unlawfully led away [the complainant's] cattle.

As I cattle have, so did it come of my own property, and so it by folkright my own is, my rearing. ${ }^{18}$

These oaths opened the lawsuit. The moot would then decide which party should be allowed to give the oath of proof. On the appointed day both parties would appear and the party allowed to give the oath of proof would swear to a set formula. To complete his oath, however, he would have to have a number of compurgators, or oath-helpers, swear to supporting formulas. The number of required oath helpers depended on their wer and on the offense being tried. They might swear, for example:

By the Lord, the oath is clean and unperjured which [the complainant or the defendant] has sworn. ${ }^{19}$

All the foreoaths, denials, final oaths, and supporting oaths had to be repeated flawlessly, "without slip or trip," if they were to

${ }^{17}$ In 1215 the Fourth Lateran Council forbade clergy to participate in ordeals. For discussion of the resistance this decree met in England, see T. Plucknetr, A Concise History of THE COMMON LAw 118-27 (5th ed. 1956).

18 Quoted in G. Rightmire, The Law of England at the Norman Conquest 37 n.117 (1932).

"Id. 
succeed. All were cast in poetic form, with abundant use of alliteration. For example, an oath used in suits affirming title to land reads as follows:

So I hold it as he held it, who held it as saleable, and I will own it-and never resign it-neither plot nor plough land-nor turf nor toft-nor furrow nor foot length-nor land nor lesow-nor fresh nor marsh-nor rough ground nor room-nor wold nor fold-land nor strand-wod nor water. ${ }^{20}$

The formality of proof and its dramatic character were connected with the fact that the law was almost entirely unwritten. "So long as law is unwritten, it must be dramatized and acted. Justice must assume a picturesque garb or she will not be seen."21 This remark echoes that of the nineteenth century German historian and linguist Jakob Grimm, who speaks of the "sensuous element" in Germanic law, contrasting this with the more abstract or conceptual element that is prominent in more "mature" legal systems. ${ }^{22}$ The expression of legal rules in poetic images helped to stamp them on the memory. Phrases like "unbidden and unbought, so I with my eyes saw and with my ears heard," "foulness or fraud," "house and home," "right and righteous," "from hence or thence"-were common. The law was contained in a multitude of proverbs. The earliest Irish law was in the form of poetry.

The dramatic and poetic qualities of Germanic law were associated with the plasticity of its substance.

Men were especially prone to express provisions relating to time and space in such a naive and inexact way as left room for chance in particular cases. It is often declared that something shall be the rule as far as a cock walks, or flies, a cat springs, as a stone or hammer is thrown, as one can reach with a sickle. A law shall endure so long as the wind blows from the clouds and the world stands ... or so much land shall be acquired as can be ridden round in a certain time on horse or ass, turned over with the plow, or covered with hides. ${ }^{23}$

This "naive and inexact" manner of expression was well suited to

${ }^{20}$ Quoted in 2 F. Palgraye, The Rise and Progress of the English Commonwealth CXXXV (London 1832).

${ }^{21}$ I have been unsuccessful in trying to locate the source of this statement. My recollection is that its author was Maitland.

22 J. Grimm, Deutsche RechtSAlterthuemer (1st ed. 1828, 3d ed. 1881), Introduction and passim. See also Grimm, Von der Poesie im Recht, 2 ZeITSCHRIFT FUR GESCHICHTLICHE RECHTSWISSENSCHAFT 25-99 (1816).

23 R. Huebner, A History of Germanic Private Law 10-11 (1918). 
the needs of peoples that had not yet acquired a scientific outlook, with its subject-object dualism. For the peoples of Europe in the Germanic era, life was much less compartmentalized than it later became, much more a matter of total involvement; hence poetic and symbolic speech, which is closely associated with the whole being, and with the unconscious, was more appropriate than prosaic and literal language, especially on solemn occasions involving the law.

Many examples of the symbolic and ceremonial character of Germanic law could be given. Land was transferred by the handing over of twig and turf or hat and glove or by the touching of the altarcloth or the bell-rope. A widow who wished to free herself from liability for her dead husband's debts would leave the house-key upon his bier. The handclasp was the usual confirmation of pledges of faith and of contracts. Various ceremonials were used in seating oneself when taking possession of land or of offices. ${ }^{24}$

The dramatic and poetic elements of Germanic law-its mimetic elements ${ }^{25}$-elevated legal speech above ordinary speech and thereby put a distance between law and ordinary life. Of course it is necessary in all societies that law be separated from the daily routine by ritual, by ceremony, and by the belief underlying ritual and ceremony-the belief in the power of certain words, put certain ways, to bring about certain effects denominated as "legal." This kind of magic is necessary if law is to work. Yet each age has its own magic, reflecting its particular concept of ultimate reality. The Germanic concept, as already stressed, postulated an essentially arbitrary Fate at the center of life; and Germanic legal magic reflected that concept.

The Germanic trial was a symbolic continuation of the bloodfeud. The parties hurled oaths at each other, instead of blows. The outcome of the ordeal, like the outcome of battle itself, was the decision of fate, of wyrd. As Gordley has put it, "The ceaseless conflict of households bent on gaining lof at the expense of each other was a cosmological principle in which all forces of nature joined." ${ }^{26}$ Ultimately, the arbitrary force of wyrd was decisive. In the words of an Anglo-Saxon poem:

Good against evil; youth against age;

Life against death; light against darkness;

Army against army; foe against foe;

Hostile with hostile shall always fight

2t Id. at 11-12.

25 See generally E. Havelock, Preface to Plato 20-35 (1963).

${ }^{26} \mathrm{~J}$. Gordley, supra note 11, at 31. 
Contending for land and avenging wrongs

A wise man must ponder this world's strife. ${ }^{27}$

The same word, dom (doom)-judgment-was used to refer to a decree of wyrd and to the outcome of a trial. In the words of Beowolf:

Often Fate saves an undoomed man, if his courage is good. ${ }^{28}$

This was the heroic side of German law: it was foe against foe locked in a deadly struggle for honor, yet each prepared to accept the wyrd's decree, however bitter it might be.

But there was another side: the community of comradeship and trust represented by the household itself. And this community carried over to the whole tribe or folk. The moot acted like a household. It had its peace, its frith (in modern German, Friede). It assembled not only to decide disputes but also to give advice and to discuss problems in an amicable way. It was concerned with establishing justice (riht; in modern English "right," in modern German Recht); the wise men, the witan ("knowing ones"), gave their opinions in an effort to hold the assembly of households together. Also, the tribe-the folk-sought to protect itself by acting collectively against wrongdoers: the judicial outcry-called in Anglo-Saxon law the "scream" or the "hue and cry" ("out! out!")—was the signal for all to join in the pursuit of the offender. A corollary of this was the characteristic penalty of outlawry in the case of the most serious offenses; theoretically, at least, none were permitted to communicate with the outlaw and he died of starvation and exposure.

The symbolism of mund (protection) and frith (peace) that characterized the household and the folkmoot, exemplified by the oath, the dramatic performing of handshakes, and other ceremonial acts of peace, was at the basis of the institutions of surety, pledge, and hostage. By swearing oaths that placed them in the protection of the gods, and later of God, the parties acquired the degree of trust necessary to enable them to submit, when they did, to compurgation and the ordeals or to accept sureties, pledges, and hostages for bot and wer. They could not violate their oaths without threatening the very basis of household and tribal life, which was itself founded on oaths.

The importance of the household within the tribe should not obscure the growing importance of bonds of lordship and territorial community. From earliest times there was a hereditary aristocracy,

27 Cotton mss. "Maxims" 48 (British Museum, London).

2* Beowulf, lines 2140-41. 
and in time lordship by service became as important as lordship by blood. H.R. Loyn writes:

Loyalty to a lord has been a consistent theme of epic poetry. From the reign of Alfred [871-900] [and among the Franks, at least from the reign of Charlemagne a century earlier] it became the cardinal moving spirit in the moulding of society. You shall fight for your kinsman when he is attacked except against your lord: that we do not permit, said a law of Alfred. Under his successors the lordless man was treated as more and more of an anomaly. Society was held together by bonds of loyalty from man to lord and from lord who was also a thegn [that is, the royal servant in the localities] to king. ${ }^{29}$

Just as bonds of lordship led up to the king as great lord, so the bonds of territorial community led up to the king as ruler of the whole land. Yet, as Loyn says, "[T] kindred power and secular lordship,"30 and similarly there was no conflict between kindred power and territorial community. The household of the lord was similar to households within the tribal community, as was the household of the king as ruler of the whole land. All were caught up in the paradigm of wyrd and lof, mund and frith, bot and wer, borh and wed; all were founded on oaths of mutual protection and service. All were part of a legal order that resolved conflict by the "binary opposites" (in Lévi-Strauss's phrase) $)^{31}$ of feud or composition of feud, with proof by ordeal or compurgation. Other characteristic institutions of this legal order were the judicial outcry when an offense was discovered (in Latin, clamor, from which we derive our legal word "claim"; in AngloSaxon hcream, from which we derive the word "scream"); outlawry, involving forfeiture of all goods and liability to be killed by anyone with impunity; and noxal surrender, that is, surrender to the victim of the object or slave by which the offense was committed.

Legal historians have given to this type of law the name Archaic Law. In its main outlines, it was characteristic not only of the Germanic peoples in the period prior to the eleventh and twelfth centuries, but also of all Indo-European peoples, from Kent to Kashmir, at one time or another in their development. Of course, there were a very great many local differences from place to place and a very

21 H. LoYN, supra note 5, at 217.

3 Id. at 300.

31 C. Levi-Strauss, Structural Anthropology 132-62 (C. Jacobson \& B. Schoepf trans. 1963). 
great many changes over time. Nevertheless, there was a common legal style. ${ }^{32}$

Of special importance in that legal style was the concept of litigation as a contest, a game; the ancient Greek name for it was agon, "a contest bound by fixed rules and sacred in form, where the two contending parties invoked the decision of an arbiter." 33 As Huizinga writes:

We moderns cannot conceive justice apart from abstract righteousness, however feeble our conception of it may be. For us, the lawsuit is primarily a dispute about right and wrong; winning and losing take only a second place. Now it is precisely this preoccupation with ethical values that we must abandon if we are to understand archaic justice. . . . It is not so much the abstract question of right and wrong that occupies the archaic mind as the very concrete question of winning or losing .... We are confronted by a mental world in which the notion of decision by oracles, by the judgment of God, by ordeal, by sortilege-i.e., by play-and the notion of decision by judicial sentence, fuse in a single complex of thought. Justice is made subservient-and quite sincerely-to the rules of the game. We still acknowledge the incontrovertibility of such decisions when, failing to make up our minds, we resort to drawing lots or "tossing up." 34

${ }^{32}$ See Watkins, Studies in Indo-European Legal Language, Institutions, and Mythology, in Indo-European ANd Indo-Europeans at 321 (G. Cardona, H. Hoenigswald, and A. Seen eds. 1970). Professor Watkins gives several examples of complex legal concepts that are common to Indo-European peoples, including one, noxal surrender, in which there is a common lexical item (sarcire in Latin and sarnikzi in Hittite) occupying the same position in the same legal structures of two societies that had no contact with each other during the period in which they used the same linguistic term. (It refers to the surrender or redemption of a slave or chattel that has caused harm to another.) Professor Watkins emphasizes that the coincidence of a linguistic equation and an institutional similarity shows a common origin where mutual influence is impossible for chronological and geographical reasons. His example "proves that the institution of noxality in Indo-European society must be as old as the community of Latin and Hittite, which is to say at the present state of our knowledge that it belongs to the common Indo-European period." Id. at 333 (footnote omitted).

Some of the common features of the Archaic Law of the Indo-European peoples are shared by contemporary primitive societies; nevertheless, modern anthropology has on the whole avoided the study of early Indo-European law, being thrown off partly by its positive implications for a theory of social evolution and partly by the fact that it cannot be studied "in the field." A. Diamond, supra note 6, is an exception, being virtually the only contemporary anthropologist who has attempted to juxtapose Archaic Law with contemporary primitive law. He fails to emphasize, however, what appears to this writer to be the most important distinguishing mark of Archaic Law, in comparison with most contemporary primitive law, namely, its emphasis on the central role of courts, that is, of formal adjudication (including both litigation and judgment), in the legal order. See notes 86-88 infra.

33 J. Huizinga, Homo Ludens: A Study of the Play-Element in Culture 76 (1955).

34 Id. at 78-79. 
In canvassing various archaic orders, Huizinga refers not only to Germanic law but also to the law of the ancient Hebrews (illustrated, for example, by the breastplate worn by the High Priest-the Urim and Thummim - that was consulted for advice and judgment), the law of the ancient Greeks (illustrated, for example, by the golden scales-the scales of justice-in which Zeus weighed men's chances of death before battle), and the law of contemporary non-literate cultures (illustrated, for example, by the institution of potlatch as well as the use of ordeals, wagers, and vows). In all these systems, the agonistic element and the playelement predominate. "The winning as such," he writes, "is, for the archaic mind, proof of truth and rightness." 35

In Rome, too, any and every means of undoing the other party in a lawsuit was held as licit for a long time. The parties draped themselves in mourning, sighed, sobbed, loudly invoked the common weal, packed the court with witnesses and clients to make the proceedings more impressive. In short, they did everything we do today. ${ }^{36}$

\section{Dynamic Elements in Germanic Law: Christianity and KINGSHIP}

The Germanic folk assembly, or moot, not only issued dooms in particular cases but also issued general decrees, which were also called dooms. The dooms, however, were not considered legislation in the modern sense; they were regarded rather as divinely inspired affirmations of ancient custom. They were the will of the gods-or, after the introduction of Christianity, the will of God. They had an objective reality. The wise men of the assembly were not called legislators but law-speakers. The law they spoke was binding because it was old; it was old because it was divinely instituted. "Right" changed slowly and surreptitiously; overt changes in the legal order required very strong justification. "Even the amendment of law [was] thought of as judgment, a speaking out of that element of law hitherto unrevealed, an act of judgment of the folk through its witan . . ..",

${ }^{35}$ Id. at 81.

${ }^{36}$ Id. at 87 (footnote omitted).

37 J. Jolliffe, The Constitutional History of Medieval England 24 (4th ed. 1961). Similarly, Fritz Kern notes of the lawmaking process in the early Middle Ages: "They do not . . . create the law; they 'discover it.' . . . Law is old; new law is a contradiction in terms .... [A]ll legislation and legal reform is conceived of as the restoration of the good old law which has been violated." F. KeRn, KingSHIP AND LAW IN THE Midde Ages 151 (1939). 
Two closely interconnected factors, however, made for conscious, overt change: one was the influence of Christianity on legal concepts; the other was the development of the kingship as a translocal and trans-tribal institution, uniting large areas containing various peoples.

One might suppose that the new religion that gradually spread through Europe between the fifth and tenth centuries would have threatened the very existence of the Germanic folklaw, which was founded in tribal myths of warring gods, in worship of rivers, woods, and mountains, in concepts of the divine descent of the tribal kings, in absolute loyalty to kinship and lordship ties, and in an overriding belief in fate. Christianity replaced the old myths with the gospel of a universal Creator, Father of all men, who once appeared on earth in the form of His Son, Jesus Christ, worship of whom brings freedom from bondage to all earthly ties, freedom from fate, freedom from death itself. These new ideas must have seemed strange and abstract to Germanic men.

Christianity also taught a more practical doctrine-that hills, valleys, forests, rivers, rocks, wind, storm, sun, moon, stars, wild beasts, snakes and all other phenomena of nature were created by God to serve man and were not haunted (as the Germanic peoples believed) by hostile supernatural deities, and that therefore it was possible for the wandering, warring tribes to settle on the land without fear. This was both preached and lived out in the fifth, sixth, seventh, and eighth centuries by tens of thousands of monks who themselves settled in the wilderness, first as hermits, then in monastic communities, and who ultimately attracted millions of people to join them in tilling the soil. Thus Christian monasticism was closely linked with the emergence of the European peasantry. Spreading across Europe from Ireland and Wales, the monastic movement fought the superstitions of nature that dominated Germanic religions, and it opposed to the pagan calendar, based on nature and the four seasons, a Christian calendar based on-biblical events and the lives of the saints. ${ }^{38}$

Moreover, Christianity appealed to the Germanic peoples by its concept of a community, the Church, which transcends kindred, tribe, and territory. On the one hand, Christianity, in contrast to Germanic paganism, treated kings not as descendants of gods but as human beings, subject like all other human beings to punishment

${ }^{3 x}$ On the monastic movement in this period, see the excellent short treatment in C. Dawson, The Making of Europe: An Introduction to the History of European Unity 176. 86 (1956). For a more detailed account, see B. Lehane, The QUest of ThreE ABbots (1968). 
by God for their sins. On the other hand, the Germanic rulers remained the supreme religious heads of their respective peoples, appointing bishops and dictating liturgical and other religious matters. In addition, they could now make wider claims to the allegiance of people of other kindreds, tribes, and territories: to bring others to the true faith, or, if they were already converted, to unite them in the true Church, became part of the mission of the Germanic rulers.

In general, Christian beliefs and practices had a great appeal to Germanic man. They brought him, for the first time, a positive attitude toward life and toward death, a larger purpose into which to fit the tragedies and mysteries of his existence. Beside them the old pagan myths seemed harsh and bleak. One can sense the passion in King Alfred's words, in the famous "Addition" to his translation of Boethius: "I say, as do all Christian men, that it is a divine purpose that rules, and not fate." ${ }^{39}$ On the other hand, the Christian cosmology and the Christian ethic were not easy for Germanic man fully to grasp. If taken seriously, they threatened to undermine not only his former system of beliefs but also his entire social order.

One may well ask why, if Christianity constituted a threat to Germanic social institutions, it succeeded in making converts among Germanic tribal chiefs and ruling families. Without discussing the struggles that took place before Christianity ultimately prevailed over the old Germanic religions, I must state immediately that the question rests on a false premise. Christianity did not, at first, constitute a fundamental threat to Germanic social institutions.

It is important not to confuse Germanic Christianity with modern Western Christianity, whether Roman Catholic or Protestant. Germanic Christianity was, in fact, much closer to Eastern Orthodoxy-both as it was then and as it still is, in some countries, today. Germanic Christianity was hardly concerned with the reform of social institutions. Nor was it primarily oriented toward ecclesiastical unity and ecclesiastical power. Its message was above all concerned with the life of the world to come-with heaven and hell-and with preparation for that life through prayer, personal humility, and obedience. The highest Christian ideals in the first thousand years of Church history, both in the East and in the West, were symbolized above all in the lives of holy men and in monasticism, with its emphasis on spiritual withdrawal from the temporal

3 King Alfred's Anglo-Saxon Version of Boethius, De Consolatione Philosophiae 224-25 (S. Fox trans. 1890). 
world. But apart from monasticism, the Church as an organization was almost wholly integrated with the social, political, and economic life of society. It did not stand opposite the political order but within it. Religion was united with politics and economics and law, just as they were united with each other. Ecclesiastical and secular jurisdictions were intermingled.

The Church taught sanctity and produced saints; this was something new for the peoples of northern and western Europe, who had previously glorified only heroes. But the Church did not oppose heroism and heroes; it only held up an alternative, higher ideal. Similarly, the Church did not oppose blood-feud and ordeals; it only said they could not bring salvation, which came from faith and good works. The majority of bishops and priests of the Church became, in fact, wholly involved in the corruption and violence that characterized the age. And this was inevitable, because they were generally appointed by leading politicians from among their friends and relatives. Christianity was Germanized at the same time that the Germanic peoples were Christianized. ${ }^{40}$ It is true that the monastic movement, by its example as much as its doctrine, attempted to teach Christian ideals of sacrifice, service, and love of neighbor-and, at the same time, scientific agriculture-to the Germanic peoples. But the myriad of monasteries that sprang up all over Europe in the sixth to tenth centuries, at first each with its own rule, offered no program of secular law reform. They offered, instead, an ascetic life of work and prayer, in preparation for the life of the world to come. They, too, had the effect of devaluing Germanic legal institutions without replacing them.

This is not to say, however, that Christianity prior to the eleventh century had no positive effect whatever on the folklaw of the European peoples. On the contrary, it produced substantial changes. In the first place, conversion to Christianity gave an impetus to the writing down of the tribal customs: one sees this in the Laws of Ethelbert, ruler of Kent, who was the first Christian king in England;41 and four centuries later in the Russkaia Pravda of the

to Cf. H. Boehmer, Das germanische Christentum, in 86 Theologische Studien und KRITIKEN, 165-280 (1913).

" The venerable Bede, writing 130 years later, said of Ethelbert that "among other benefits that he conferred upon his people, he enacted judgments for it with the advice of his councillors according to the examples of the Romans" (decreta illi iudiciorum iuxta exempla Romanorum cum consilio sapientium constituit). BEDE, Historia Ecclestae II, 5. Wallace-Hadrill points out that the phrase iuxta exempla Romanorum should not be taken to mean that the legislation was enacted after the manner of the Romans "but rather that Ethelbert followed Roman patterns or copies, such as the Salic Law and various Burgundian, Gothic, and Lombard examples, which Augustine had brought with him from Italy." J. 
first Christian princes of Kievan Rus. ${ }^{42}$ For one thing, Christianity brought writing, and writing made it possible to fix customs (and especially customary monetary sums) that might otherwise be uncertain. This facilitated the negotiation of dispute-settlement; it also strengthened the incipient jurisdiction of public authorities to punish the most serious forms of crime. In addition, the sacred writing of the Bible suggested a way of attaching a new kind of sanctity to custom-the writing was itself a ritual. Secondly, the writing down of the customs gave an opportunity to make some subtle-as well as some not-so-subtle-changes in them. For example, the Christian clergy, who became the king's advisers, and who had the gift of writing, wanted protection. Indeed, they needed special protection since they were, in a sense, outside the tribal system; they were, to some extent, a people without kin. It is no accident that the Laws of Ethelbert start: "Theft of God's property and the Church's, shall be compensated twelve-fold . . . ."43

Nor were all the changes that Christianity wrought in the folklaw attributable to political factors. In the long run, moral factors probably played an even greater part. The Germanic "codes" contain strong exhortations in favor of more just and humane legal values. The Laws of King Alfred, for example, begin with the Ten Commandments, a restatement of the laws of Moses, a summary of

Wallace-Hadrill, Early Germanic Kingship in England and on the Continent 37 (1971). Wallace-Hadrill adds that at least 19 of Ethelbert's 90 chapters have parallels in the Lex Salica, and that there are parallels with other Germanic codes as well. He writes: "The bringing of exempla witnessed the link that existed in Roman minds between conversion and law; it was so in Gaul, in Spain, and in Italy; and certainly in Kent." Id. at 39.

Nevertheless two leading English legal historians, in their efforts to disprove foreign influences on English law, have gone so far as to claim that Ethelbert's laws were "entirely pagan in origin" and were "probably" promulgated before the introduction of Christianity into England in 597. H. Richardson \& G. SAyLES, LAw and Legislation From AETHELBERT to MaGna CARTA 2-12 (1966). In refuting this view, Wallace-Hadrill points out that Ethelbert's laws were within the body of a legal tradition that included Frankish, Burgundian, and other Germanic laws. Pope Gregory the Great, in sending a mission of forty-strong (plus interpreters), headed by Augustine, to accomplish the conversion of Ethelbert, wrote to the English king that by turning to the true faith he would be blessed by God even as the Emperor Constantine had been blessed. As Wallace-Hadrill writes, the Pope thereby

meant it to be understood that the new convert was entering the family of Catholic kings of whom the emperor [in Constantinople] was the father. Papal and imperial correspondence of the period leaves no doubt about this. . . . Politically this might mean little or nothing. But one certain consequence would be that the new convert would enter into the tradition of written law of which the emperor was the fountainhead. This is one reason why Aethelberht's laws must be dated after his conversion. Lawbooks were a Roman, and specifically a Christian-Roman, gift to the Germanic kings.

J. WALLACE-HADRIL, supra at 32.

$\$ 2$ Russkaia Pravda (Iaroslav's Pravda) may be found in English translation in G. VERNadsky, Medieval Russian Laws (1947).

t3 Laws of Ethelbert, supra note 7, $\$ 1$. 
the Acts of the Apostles, and references to the Penitentials and to other laws of the Church. Alfred's laws themselves, although largely consisting of a recapitulation of earlier collections, contain such striking provisions as "Doom very evenly: doom not one doom to the rich, another to the poor; nor doom one to your friend, another to your foe." 44

Christianity broke the fiction of the immutability of the folklaw. Gradually, in the sixth to the eleventh centuries, Germanic law, with its overwhelming biases of sex, class, race, and age, was affected by the Christian doctrine of the fundamental equality of all persons before God: woman and man, slave and free, poor and rich, child and adult. These beliefs had an ameliorating effect on the position of women and slaves and on the protection of the poor and helpless. Christianity also had an important effect on judicial proof by oaths, since the swearing of oaths now took Christian forms and was supported by ecclesiastical sanctions. That is, oaths were administered by priests in churches, at altars, on relics, and accompanied by appeals to divine sanctions against falsehood; and false swearing was subject to discipline through eccelsiastical penances. ${ }^{45}$ Indeed, oaths took a place alongside ordeals as a principal mode of trial. Ordeals were retained for trial of those who had no kin to swear for them, for those who for some other reason failed to produce the necessary oath-helpers, and for those of notorious ill-repute whose oaths were wholly unreliable, as well as for certain designated crimes. In other cases, however, an equally common method of proof came to be that of compurgation. As before, oath-helpers were drawn chiefly from kinfolk, and the practice of compurgation involved a strong element of loyalty, which is indeed implicit in the concept of oath-helping. But the Church added the risk of offending God Himself by. perjury, and the duty, if one did commit perjury, of confessing the sin to a priest and being subjected to penitential discipline. Moreover, not only the false swearing of oaths but also all other obstructions of justice were considered to be sins subject to penitential discipline. For example, persistence in blood-feud after a reasonable offer of satisfaction was an offense against God, to be confessed to a priest and atoned for by fasting and other forms of penance.

Christianity also enhanced the role of kingship in the development of the folklaw during the period prior to the late eleventh

"The Laws of Alfred may be found in F. Attenborough, Laws of the Earliest English KINGS 62-93 (1922).

${ }^{4}$ A. Diamond, supra note 6, at 300. 
century, especially the king's responsibility to see that tribal justice was tempered with mercy and that the poor and helpless were protected against the rich and powerful. In the eighth, ninth, tenth, and eleventh centuries, Frankish and Anglo-Saxon kings were thought to be appointed by God to act as judges in extraordinary cases. As they moved about their realms-and they were continually moving, for otherwise there were few means of communication-they heard cases for mercy's sake: cases of widows or orphans or men who had no families to protect them, or no lords; cases of the very worst crimes for which no money payment could be satisfaction. This was part of their spiritual jurisdiction as patriarchs of their people.

Politically, Christianity served to raise to a new height the authority of the king-indeed, to transform him from a tribal chief $(d u x)$ into a king (rex). Once converted to Christianity, the king no longer represented only the deities of his tribe; he now represented, in addition, a universal deity whose authority extended to all tribes, or at least to many tribes. Although Christianity was undoubtedly Germanized in this period, nevertheless, it was a unifying ideology. Under its banner Charlemagne, who ruled the Franks from 768 to 814, and who was crowned Emperor in 800, mobilized the various people of his empire into a unified army for wars against Arabs, Saxons, Danes, and Slavs, while across the Channel Mercian kings (and a century later the Saxon king Alfred the Great) established military hegemony over the various races of England and eventually drove out the Scandinavian invaders. The universality of the imperial kingship came to prevail-at least for various periods of time-over tribal, local, and household loyalties: a universality based not only on military power but also on the spiritual authority of the king (or emperor) as head of the Church. Charlemagne called Church councils and made Church law-even before he agreed to be crowned Emperor by the bishop of Rome. And Alfred was head of the Church in England. ${ }^{46}$ As stated in the laws of Ethelred (about

" See C. Dawson, supra note 38, at 190-201. Under Charlemagne the Frankish state was to an even greater extent than the Byzantine Empire a church-state ... . The King [was]: the governor of the Church as well as of the State, and his legislation [laid] down the strictest and most minute rules for the conduct of the clergy and the regulation of doctrine and ritual. ... The government of the whole Empire was largely ecclesiastical, for the bishop shared equally with the court in the local administration of the 300 counties into which the Empire was divided, while the central government was mainly in the hands of the ecclesiastics of the chancery and of the royal chapel .... The control and supervision of the local administration was ensured by the characteristic Carolingian institution of the Missi Dominici, who went on circuit through the countries of the Empire, like the [later] English judges of assize, and here, too, the most important 
1000 A.D.), "A Christian king is Christ's deputy among Christian people and he must avenge with utmost diligence offenses against Christ." ${ }^{47}$

On the whole, despite some tensions between popes and emperors, the clergy supported the imperial concept, including imperial leadership of the Church itself. The concept of the Church as an independent organization distinct from secular authority only emerged in the eleventh century: the Papal Revolution, by sharply opposing ecclesiastical to secular government, laid the foundation for the Western legal tradition. Prior to that time popes, bishops, and priests were appointed by emperors, kings, and lords.

In the earlier period as well, however, both the royal and the ecclesiastical authority were dynamic factors in the development of legal institutions. Especially from the eighth century on, the kings extended their peace-their household law-beyond their own families, courts, friends, servants, and messengers. Even in the sixth and seventh centuries they had made very strong efforts to regulate and limit the blood-feud; they had, for example, exacted payment from persons and households for certain offenses even when their own royal household peace had not been violated. Gradually, more and more offenses became triable before the king. Treason, intentional

missions were entrusted to bishops and abbots.

Id. at 190. As for the Papacy, "Charles regarded the Pope as his Chaplain, and plainly tells Leo III that it is the King's business to govern and defend the Church and that it is the Pope's duty to pray for it." Id. at 191. Dawson cites Alcuin, the great Anglo-Saxon adviser of Charlemagne, who wrote that there are three supreme powers in the world-the Papacy at Rome, the Empire at Constantinople, and the royal dignity of Charles-and of these the last is highest since Charles is appointed by Christ as the leader of the Christian people (populus (hristianus). Id. at $257 \mathrm{n}$.1. Alcuin changed the phrase imperium Romanorum in the Church liturgy to imperium Christianum, referring to Charles' own empire, which transcended both Rome and Romans.

On the "sacral kingship" in England, and on Alfred's role as head of the Church, see W. Chaney, The Cult of Kingship in Anglo-Saxon England (1970), especially chap. VI, "Sacral Kingship in Anglo-Saxon Law." Chaney writes that

the most fundamental concept in Germanic kingship is the indissolubility of its religious and political functions. ... [The king] is not a god and not all-powerful, but he is filled with a charismatic power on which his tribe depends for its well-being. This is the king's mana ... [which] permeates not the king alone but the entire "royal race," the whole kin from among whom the folk elect him ....

Id. at 13,15 . The "sacral kingship" was carried over into the Christian period; there was no division between the secular and spiritual spheres, and the King was Christ's deputy in both, who "must legislate on ecclesiastical as well as on secular matters-that is, on the totality of his kingdom's well-being under God and the king." Id. at 192. "The king was still the head of the folk under divine auspices, and a separation of religion and royal function was as unthinkable as under paganism. . . The ruler was expected to play a theological and eschatological role for his folk." Id. at 247.

5 VIII Aethelred ๆ 2 \$, in The Laws of the Kings of England, from Edmund to HenRY I 119 (J. Robertson ed. \& trans. 1925). 
homicide, and adultery were made capital offenses. In the eighth and ninth centuries the Frankish emperors, and in the ninth and tenth centuries the Anglo-Saxon kings as well, openly undertook responsibility for maintaining the king's peace throughout their territories. In the oath composed by Archbishop Dunstan of Canterbury for the coronation of King Edgar in 973, Edgar swore that "true peace" should be assured to all "Christian people" in his kingdom, that robberies and "all unrighteous deeds" should be forbidden, and that "justice and mercy" should govern resolution of all disputes. ${ }^{48}$ The Frankish emperors had for some time sworn similar oaths. In time, such oaths were implemented through the appointment of royal officials to supervise local assemblies and through other administrative devices for maintaining royal influence over the tribes and localities. An incipient feudalism, in which the king had the role of chief lord, also served to reinforce his peacekeeping function.

Kings and bishops issued new laws and held court. In so doing they were influenced in a very general way by the heritage of Roman law that the Church had carried over from Byzantium to the West. Also, the needs of the royal and ecclesiastical bureaucracy generated new legal institutions more sophisticated than those of the tribal, local culture. For example, royal delegates summoned inquests (juries) and interrogated witnesses. Royal edicts as well as ecclesiastical decisions and decrees came to constitute an important source of law. Thus an official law (Amtsrecht, as Rudolph Sohm called it) grew up alongside the folklaw (Volksrecht). ${ }^{49} \mathrm{~A}$ modern parallel is the reception of a Western type of law in Japan and China in the late nineteenth and early twentieth centuries-a Western type of law that governed certain official and upper-class relations but that left virtually unaffected the traditional legal order among the people as a whole.

So in Europe, until the latter part of the eleventh century, the basic contours of the folklaw remained tribal and local, with some feudal elements. The kinship bond continued to provide the primary definition and the primary guarantee of a person's legal status. $^{50}$ The kings took little initiative in making the folklaw. There

4" The Laws of the Kings of England from Edmund to Henry I 43 (J. Robertson ed. \& trans. 1925).

19 Sohm, Fränkisches Recht und römisches Recht, 1 Zeirschrift der SAvignY-STIFTUNG FÜR RECHTSGeSchichte, RoManistische ABTEIUNG 1 (1880).

so The presence of a kin capable of vouching for [a man's] good behavior, and of taking vengeance if he were wronged or slain, is all-important. . . . If a man was in prison, his kindred fed him. If captured by his enemies after taking sanctuary, after siege in his own house, or after peaceful surrender in open country, his kindred were to be informed within thirty days. If he was taken in theft or accused of witchcraft or incendiarism, his 
was virtually no royal law of contract, or of property, or of landlord and tenant, and very little royal law of crime and tort. When kings did succeed in establishing some degree of administration of the localities by royal delegates, the latter tended to be swallowed up by the localities that they were supposed to administer in the king's behalf or else they became their own masters. The written collections of laws that kings occasionally promulgated, setting forth customs that needed to be better known or more firmly established, were not legislation in the modern sense but were rather in the nature of exhortations to keep the peace, do justice, and desist from crime. The king had to beg and pray, as Maitland put it, for he could not command and punish. Indeed, Germanic laws contain provisions stating that when a person had exhausted his opportunities in the local courts, he should not go to the king for a remedy.

Undoubtedly, one factor in the weakness of the central authority was economic and technological: despite some increase in commerce and some growth in the number and population of towns during the eighth, ninth, tenth, and first half of the eleventh centuries, despite the improvement of agricultural technology, despite the growth of handicrafts and a general advance in the arts and in learning, the economy remained almost entirely local and the existing technology did not permit efficient communication between the center and the periphery. These economic and technological factors were connected with underlying religious and political factors: the legitimacy of the central authority was based on Christianity, whose world outlook was in sharp conflict with that of Germanic tribalism, with its belief in honor and fate; and the central authority lacked a concept of the independent role of law as a means of effectuating Christian concepts and values and of rationalizing and controlling social, economic, and political processes. The dynamic elements of

kindred could stand surety for him. If the kindred refused to do so, he was condemned to penal slavery or to death. If he was slain during his first year as a penal slave, his kinsmen were to receive his wergeld. ... In case of death at young age the kindred took on responsibility for maintaining the heir.... The kindred certainly possessed extensive authority over landed property. ... . But for all its importance in these social matters, in ensuring a man's standing in law, in providing him with compurgators who would swear to his innocence or to his good name in court, the kindred took on its most spectacular aspect, and also its most significant, in relation to two closely related institutions: the payment of wergeld and the waging of vendettas. If a man were killed by violence then his kindred had the right to wage a feud against the slayer's kindred. Such a feud could be composed. The spear could be bought off; and the wergeld was the sum payable by kindred to kindred for this composition. It was the blood-price . . . .

H. LOYN, supra note 5, at 292. Loyn is describing Anglo-Saxon law, but his description is equally applicable to Frankish law and the laws of all the peoples of Europe during the fifth and sixth to the tenth and eleventh centuries. 
the law were unsystematized and weak; the static elements predominated. Law was conceived primarily as an expression of the unconscious mind of the people, a product of their "common conscience" (in the words of Fritz Kern), ${ }^{51}$ rather than primarily as a deliberate expression of conscious reason or of will. It was, in that respect, like art, like myth, like language itself.

\section{Pentential Law and Its Relation to the Folklaw}

Deeper insights into the nature of the legal order that prevailed in Europe prior to the late eleventh and twelfth centuries may be gained by examining more closely the system of penances introduced by the Western Church-or rather, the churches, for despite the great prestige of the bishop of Rome, there was as yet no separate, corporate, organized Roman Catholic Church in the West, no unified legal entity, but rather an invisible spiritual community of individual bishoprics and monasteries subordinate to tribal and territorial and feudal units as well as to kings and emperor.

The system of penances not only reinforced the folklaw, as mentioned earlier, but also constituted an independent body of ecclesiastical criminal law, which the folklaw in turn reinforced. Its origins were in the monasteries. Each monastic community had its own miniature legal order, its own "rule" of work and prayer and of administration and discipline. Each was independent, subject only to the ultimate control of the bishop of the diocese. Starting in the sixth century, various leading abbots wrote collections of rules, called "penitentials," assigning specific penances for various sins. ${ }^{52}$ At first, varying numbers of strokes or blows were assigned for differ-

\section{Kern writes:}

[Customary law] quietly passes over obsolete laws, which sink into oblivion, and die peacefully, but the law itself remains young, always in the belief that it is old. Yet it is not old; rather it is a perpetual grafting of new on to old law, a fresh stream of contemporary law springing out of the creative wells of the sub-conscious, for the most part not canalized by the fixed limits of recorded law and charter.

.. . Customary law resembles the primaeval forest which, though never cut down and scarcely changing its outline, is constantly rejuvenated, and in a hundred years will be another forest altogether, though outwardly it remains the same "old" wood, in which slow growth in one part is accompanied by an unobserved decay elsewhere.

F. KERN, supra note 37, at 179.

52 There is a relatively small but valuable body of literature in English on the Penitentials, including: J. McNeill \& H. Gamer, Medieval Handbooks of Penance: A Translation of the Principal Libri Poenitentiales and Selections from Related Documents (1938); J. McNeill, The Celtic Penitentials and Their Inpluence on Continental Christianity (1923); T. OAKley, English Penttential Discipline and Anglo-Saxon Law in Their Joint INFLUENCE (1923); and several articles by McNeill cited in the Introduction to MEDIEval Handoooks of Prnance, supra. The role of the Penitentials in the monastic movement of the sixth to tenth centuries is vividly portrayed in B. LeHANE, ThE QUEST of ThreE AzBots (1968). 
ent forms of misconduct, ${ }^{53}$ but in time the usual penance came to be fasting at certain times, supplemented by alms, good works, and compensation of victims. Thus Christian monasticism, without denouncing the old communal methods of dispute resolution and punishment, offered its own procedures, which were more concerned with the care of souls than the appeasement of vengeance.

Soon Penitentials came to be written not only for the discipline of monks but for the discipline of the whole Christian people. By the eleventh century there were scores of such Penitentials circulating among the clergy of the peoples of the West. They spread (like the monastic movement itself) from the Irish and Welsh to the AngloSaxon and Frankish kingdoms, including the Eastern territories of the Frankish empire, to Spain, to Lombardy, to Rome itself, and to Scandinavia as well. They were wholly unofficial collections of rules compiled by individual clerics and were intended not to bind but rather to guide priests in their treatment of persons who confessed their sins. They differed widely in character in different places and in different centuries.

The origins of the Western Penitentials are to be found in the practice of the Church, during the first centuries of the Christian era, of requiring public penance for heinous sins. In the early centuries all penitents were required to present themselves at a certain time or times during the year to the bishop who, in a solemn and elaborate church ceremony, sentenced them, according to the gravity of their sins, to varying terms of fasting and deprivation of the sacraments. For example, the fourth century Canonical Letters of Basil the Great specified various penances for various sexual or marital offenses such as rape, adultery, second marriage ("digamy"), and incest; for religious offenses such as magic, idolatry, and violation of graves; and for what at a much later period would be called secular offenses, such as homicide of various kinds, theft, perjury, abortion, and infanticide. ${ }^{54}$ The sacrament of penance was supposed to effectuate a permanent reconciliation with God and neighbor. Therefore there was only one penance, just as there was only one baptism. As a result, penance came generally to be postponed until the end of life. ${ }^{55}$

The practice of public penance survived only fitfully in the West after the fifth century. Under Celtic influence it was largely

33 See The Monastic Rule of Columban (ca. 600), in J. McNeILL \& H. GaMER, supra note 52, at 257-65. See also B. LeHANE, supra note 52, at 156-62.

34 See T. OAKLEY, supra note 52, at 25.

s5 See.B. Spochmann, Penance and the Anointing of the Sick 104-09 (F. Courtney trans. 1964). 
replaced by private penance, which could be repeated at will, with secret confession by each individual to a priest and secret imposition of the duty to perform penitential acts. Many types of offenses covered by the Western Penitentials were derived from the earlier Eastern practice, but new types were added. "Secular" crimes were also sins; in fact, the words "crime" and "sin" were used interchangeably. The Penitentials often distinguished between major sins, called "chief crimes" (capitalia crimina) and minor sins (peccata minora); the chief, or capital, crimes were not defined in terms of acts but rather in terms of states of mind or motivations; there were usually eight-pride, envy, unchastity, anger, bitterness (accidia, sometimes called tristitia seculi, "sadness of the world"), vainglory, gluttony, avarice. ${ }^{56}$ The penances for the same type of act-say, homicide-varied according to the motivation of the actor when he committed the act, as well as according to other circumstances. The particular penance imposed by the priest was left to his own discretion, guided by the Penitentials.

The Penitentials established no trial procedure, although in time they came to indicate the types of questioning that priests should use. The procedure was that of the confessional. Penances were applicable to sins that were confessed to a priest. Typically, the confession was informal and private. The priest was under a sacred duty not to divulge it. However, in some Penitentials (especially Frankish Penitentials of the ninth and tenth centuries, which opposed the Celtic tradition in this respect), public penance was preserved for notorious $\sin ^{.7}$ But whether public or private, the penitential system rested ultimately on the consent of the individual offender to confess and to do penance and, of course, on the strong social pressure of the community that evoked such consent.

Although the Penitentials usually stated the penance for a given $\sin$ in terms of a certain number of days, months, or years of

st See generally id. at 5-121. Cf. The Penitential of Cummean (ca. 650), in J. McNertL \& H. GAMER, supra note 52, at 98-111 (describing "medicines" for the eight principal vices).

s2 Boniface, the Anglo-Saxon monk who played a principal role in the conversion of what we now call Germany, opposed the Celtic emphasis on private penance. A capitulary of Charlemagne written in 813 contained the demand, "open sin, open confession," and in 847 the Council of Mainz ruled that there should be public penance for public crimes, but McNeill indicates that these provisions were not regularly enforced under Charlemagne's rule. J. McNeILL, supra note 52 , at 173 . On the other hand, public penance continued to be practiced at least as a wholly voluntary matter. Thus one tenth century Frankish Penitential states: "At the beginning of Lent all penitents who are undertaking or have undertaken public penance shall present themselves to the bishop of the city before the doors of the church, clad in sackcloth, with bare feet, with their faces downcast toward the earth . . . " Penitential Canons from Regino's Ecclesiastical Discipline, Canon 295. J. MCNEILL \& H. GaMER, supra note 52 , at 315 . 
fasting, they also provided for a great variety of alternative types of atonement, including prayers and vigils, reading of psalms, and pilgrimages. Stated penances also included compensation of victims and assistance of their relatives; for example, in cases of beating, the offender might be required to pay for medical treatment of the victim, to do his work, and to make compensation. Property that was stolen or property fraudulently obtained or withheld was subject to restitution. ${ }^{58}$ Also the practice developed from an early time of permitting substitution of one type of penance for another in cases of necessity. For example, if a person were too ill to fast he might be permitted to substitute a certain number of readings of psalms. Eventually, commutation into monetary payments was introduced, after the fashion of the folklaw, as were payments by kinfolk in exceptional cases. This led to various forms of penance by proxy, including vicarious penance by priests singing masses on behalf of the sinner. Commutation of long sentences of fasting and prayer, moreover, sometimes took bizarre forms, such as sleeping in water, on nut-shells, or with a dead body in a grave, or reciting a psalm seven times while standing with arms extended like a cross (called "honest cross-vigil").

Bishop R. C. Mortimer is right, in a sense, in charging that such devices "[reduced] to an artificial formality the whole scheme of penitence and restoration to grace." 59 On the other hand, they did not have the same significance in the Germanic era that they acquired later. For one thing, money payments for offenses and group atonement were central features of Germanic law. For another, penitential discipline, prior to the late eleventh and twelfth centuries, had not yet become a scientific system of rules and procedures. The absolute duty to confess before taking the sacrament of holy communion had not been established. The sacraments in general had not yet been legalized. The penitential system left great leeway for variations of method, and even of principle, among the various bishoprics and monasteries and even, possibly, parishes. Above all, the priest was not conceived to have the power to absolve the penitent from the consequences of his sin. At most, the priest could pray that as a result of the penance God or St. Peter or one of the other saints would absolve him. Only in the post-Germanic period, that is, the late eleventh and twelfth centuries-after the Church had estab-

s8 See T. OAKLEY, supra note 52, at 169-74. In cases of homicide, in addition to the usual types of penance, the offender was required to satisfy the friends of the slain (this probably refers to wergeld) and render service to the father and mother. Id. at 170.

39 R. Mortimer, Western CANon LaW $28-29$ (1953). 
lished itself as a legal entity, after the legal concept of representation had been fully developed, and after the sacraments had become legalized-did it become possible for the priest to say, "Ego absolvo te ...."60

The basic conception of the Penitentials was that penance was medicine for the soul. Thus the Penitential of Burchard of Worms, written about 1010 A.D., opens with the following words:

This book is called "the Corrector" and "the Physician," since it contains ample corrections for bodies and medicines for souls and teaches every priest, even the uneducated, how he shall be able to bring help to each person, ordained or unordained; poor or rich; boy, youth, or mature man; decrepit, healthy, or infirm; of every age; and of both sexes. ${ }^{11}$

The idea of punishment was subordinated to the idea of cure; and cure was envisioned as the establishment of a right relationship to God, that is, to life as a whole, including the life of the world to come. The ultimate penance was excommunication, which signified deprivation of the right to participate in the sacraments of the Church (communion, marriage, burial, and others); this purported to cut off-temporarily - the relationship of the sinner to God and to the Church until by faith and works he prepared himself for reconciliation. It was an extreme measure, which had an effect similar to outlawry, since curses were heaped not only on the offender but also, prospectively, on anyone who came to his assistance. For the most part, the penances were more subtle. There was a general theory, derived from medical concepts of the time, that "contraries are cured by their contraries." "The duty of a physician is to cool what is hot, to warm what is cold, to dry what is moist, and to moisten what is dry." ${ }^{62}$ This found reflection, for example, in the provision of the Penitential of Columban that "the talkative person is to be sentenced to silence, the disturber to gentleness, the gluttonous to fasting, the sleepy fellow to watchfulness." 63 For the shedding

" $C$ f. J. MCNEIL, supra note 52, at 185 (suggesting that the first use was in the early thirteenth century). The earlier formulae were in the subjuncrive: Ipse te absolvat, or Absolvat te sanctus Petrus et beatus Michael archangelus. Id. at $185 \mathrm{n} .2$. In the first part of the thirteenth century it was common to use the declaratory formula, Ego absolvo te auctoritate domini Dei nostri Jesu Christi et beati Petri Apostoli et officii nostri. Id. at 185 n.3.

"See Selections from the Corrector and Physician of Burchard of Worms, in J. McNenL \& H. GAMER, supra note 52, at 323. The formula "medicine for souls" goes back to much earlier times. Thus the Penitential of Cummean starts with the words: "Here begins the Prologue of the health-giving medicine of souls." Id. at 99.

12 This was the formula of Alexander of Tralles (525-605), the greatest medical authority of the period. J. McNeILI \& H. GAMER, supra note 52, at 44.

is Penitential of Columban (ca. 600), A. 12, in J. McNeml \& H. Gamer, supra note 52, at 251. 
of blood, renunciation of weapons was normally required; for unchastity, abstention from marital intercourse.

Yet a wide variety of variations and substitutions were permitted, depending on the individual offender. As the Preface of the Penitential ascribed to Bede states:

For not all are to be weighted in one and the same balance, although they be associated in one fault, but there shall be discrimination for each of these, that is: between rich and poor; freeman, slave; little child, boy, youth, young man, old man; stupid, intelligent; layman, cleric, monk; bishop, presbyter, deacon, subdeacon, reader, ordained or unordained; married or unmarried; pilgrim, virgin, canoness, or nuns; the weak, the sick, the well. He shall make a distinction for the character of the sins or of the men; a continent person or one who is incontinent, wilfully or by accident; [whether the sin is committed] in public or in secret; with what degree of compunction [the culprit] makes amends by necessity or by intention; the place and times [of offences]. ${ }^{64}$

"In this way," as Bishop Mortimer states, "casuistry and moral theology found their way into canon law." 65

The law of penance, codified in the Penitentials, contrasted sharply in many respects with the folklaw as it had developed since pre-Christian times. The folklaw was concerned primarily with the control of the blood-feud; the penitential law of the church was concerned primarily with the care of souls. The folklaw based its sanctions for inflicting harm principally on the extent of the harm; the penitential law of the Church based its sanctions for inflicting harm principally on the character and degree of the offense. The folklaw rested fundamentally on concepts of honor and fate; the penitential law of the Church rested fundamentally on concepts of repentance and forgiveness. The folklaw was directed primarily toward the repression or forestalling of violent conflict within the tribal, local, and lordship community; the penitential law of the Church was directed primarily toward the preservation of the spiritual welfare of the community of the faithful and the preparation of their individual souls for eternal life.

Yet despite these contrasts, the penitential law and the folklaw belonged to the same culture. All major "secular" offenseshomicide, robbery, and the like-were also sins to be atoned for

64 J. McNeIll \& H. Gamer, supra note 52, at 223 (possibly early eighth century).

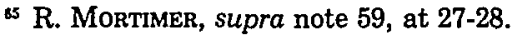


by penance. All major "ecclesiastical" offenses-sexual and marital sins, witchcraft and magic, breaking of vows by monks, and the like-were also crimes prohibited by the folklaw and subject to "secular" sanctions. In fact, the "secular" authorities who administered the criminal law were largely clerics. One cannot speak, therefore, of a separation of "secular" and "spiritual" law, or of "secular" and "ecclesiastical" law, in this period of Western history. The folklaw and the penitential law covered the same ground, so to speak. Of course, they covered it in different ways. The writings of the time, from the sixth to the early eleventh centuries, referred to the two ways in terms of "worldly law," or "man's law," on the one hand, and "God's law," on the other. But what we would today call the State and the Church were both equally concerned with each kind of law. A good illustration of this may be found in a provision of the laws of the Anglo-Saxon King Ethelred: "And he who henceforth in any way violates right laws of God or man, let him expiate zealously . . . as well through divine penance as through worldly correction." 66 Thus the penitential laws were enforced by the king and declared by him to be applicable to all offenses, whether against God or man. Another illustration may be found in the address of one of the Missi Dominici sent out by Charlemagne to check on local administration. "We have been sent here," he begins, "by our Lord, the Emperor Charles, for your eternal salvation, and we charge you to live virtuously according to the law of God, and justly according to the law of the world." "77 Frankish and Anglo-Saxon kings, moreover, often issued laws requiring ecclesiastical penances to be enforced against violators of worldly law.

The folklaw, having only weak means of enforcement, needed the support of the penitential law in order to maintain its own sanctity, especially to maintain the sanctity of the oaths on which it came to rest. Beyond that, the penitential law reinforced the folklaw's emphasis on negotiated settlement. As mentioned above, failure to accept a reasonable offer of composition of blood-feud was a sin requiring penance under ecclesiastical law. In addition, penitential law strongly encouraged the "trust" side of the "trustmistrust" syndrome characteristic of primitive societies. ${ }^{68}$ The Penitentials appropriated the Germanic word for compensation (in Anglo-Saxon, bot) as the word for penance. Bot was paid for injury to God; it was sometimes called god-bot in the Anglo-Saxon Peni-

\footnotetext{
" VI Aethelred If 50 (author's translation).

7 Quoted in C. Dawson, supra note 38, at 218.

"See note 16 supra.
} 
tentials and Anglo-Saxon law generally, and sometimes just bot. The verb form, gebete, meant "repent of," "expiate," "atone for." The bot imposed by priests for sins against God had elements of atonement and expiation, as well as of restitution. The offer of bot to the victim, and/or his kinfolk, was thus an offer of reconciliation that he and/or they had to respect. It was also an offer that the sinner was required to make-not by the folklaw but by divine law. It is not surprising that folklaw bot itself became permeated with concepts of atonement and reconciliation drawn from the penitential bot. The first book ever written in the West to describe a secular legal order, a manual of the early twelfth century called Laws of Henry the First (Leges Henrici Primi), ${ }^{69}$ followed the tradition of the Penitentials in emphasizing that English law prefers friendly settlement (amor or amicitia) to litigation (iudicium). ${ }^{70}$

Over a century before the Leges Henrici Primi a code of Ethelred had stated: "Where a thegn has two choices, love or law"-that is, composition or judgment-" and he chooses love, it shall be as binding as judgment."71 Lady Doris M. Stenton writes that the importance of this statement, which reappears in Latin in the Leges Henrici Primi, lies in the fact that a judicial decision is "likely to leave one party dissatisfied and in mind to make trou-

"2 Leges Henrici Primi (L. Downer ed. \& trans. 1972).

${ }^{70}$ The unknown author, who was probably an ecclesiastic in the court of the English king, wrote: "All causes are . . . preferably to be settled by friendly concord" (pax). "Those whom the county court finds in dispute with each other it shall bring together in friendly agreement (amor) or it shall let a judgment stand in settlement between them." "But if an oath of reconciliation (juramentum pacationis) is demanded, the offender shall swear . . . that if the accuser were in the same position ... he would accept the offer of compensation or renounce any amends ....." "If anyone makes amends to another for his misdeed . . . and afterwards for the purpose of effecting a friendly accord (amicitia) with him offers him something along with an oath of reconciliation (pacis), it is commendable of him to whom the offer is made if he-gives back the whole thing and not retain any suggestion of the affront (contumelie) to himself." "Where any of them has the choice ... of amicable agreement ..., this shall be as binding as a legal decision (judicium) itself." "Concerning disputes between neighbours ... they shall meet at the boundary court of their lands, and the person who makes the complaint first shall have justice first. If a dispute ought to be taken elsewhere, they shall proceed to the court of their lord . . . and in his court friendly agreement shall bring them together (eos amicitia congreget) or a formal judgment shall stand between them (sequestret judicium); if the situation be otherwise they shall proceed to their hundred court if need be." "For it is a rule of law that a person who unwittingly commits a wrong shall consciously make amends. He ought, however, to be the more accorded mercy and compassion at the hands of the dead man's relatives the more we understand that the human race grows sick with the harshnesses of a cruel fortune and with the melancholy and wretched lamentation of all." LEGES HENRICI PrIMI (author's translation). I am indebted to Stephen D. White for leading me to these passages. See note 74 infra.

$"$ Quoted in D. Stenton, English Justice Between the Norman Conquest and the Great Charter, 1066-1215 at 7 (1964). 
ble."72 She goes on to note that in records of Anglo-Saxon lawsuits of the tenth and eleventh centuries "it is remarkable how often a party who has been completely successful in the pleadings comes at last to a compromise leaving his opponent possessed for life of the land at issue." "73 What Lady Stenton writes of Anglo-Saxon law is confirmed by reports of Frankish and other European cases of the time. As Stephen White reports, disputes both in England and on the Continent in the tenth and eleventh centuries were often concluded by formal compromises symbolized in the exchange of gifts, which were clearly tokens of friendship and mutual trust. White adds that such formal settlements were often reached through the good offices of mediators, sometimes referred to as "friends and neighbors." 74

We should not, however, exaggerate the influence of the Penitentials, or of the Church's law of penance, on the folklaw in the period from the sixth to the tenth centuries. The Christian division between God's law and the world's law encouraged and supported some of the softer tendencies of the world's law, especially what Max Gluckman, referring to contemporary primitive societies, has called "the peace in the feud."75 But Christianity did not in those centuries alter the Germanic folklaw in its fundamental structure. It could not do so, if only because the Church as an institution-outside the monasteries-was wholly integrated into Germanic society. Viewed in the abstract, the conflict between the Christian and the Germanic world-views was incredibly sharp: caritas against honor, mercy against fate, a peaceful and harmonious natural order against a natural order haunted by demonic forces, eternal salvation against sacred temporal values associated with kinship and kingship. But the conflict in world-views was not carried over into social action. With regard to social institutions, Christianity at that time took for the most part an essentially passive position. Even after the development under Charlemagne of the concept of the king as ruler of the "Christian empire," pagan social institutions continued to prevail. The kingship, Wallace-Hadrill writes,

has been transformed into an office with duties and rights defined by churchmen . . . . Should we now call kingship Chris-

72 D. STENTON, supra note 71 , at 7.

Id. at 8.

"S. White, 'Pactum . . . legem vincit et amor iudicium': The Settlement of Disputes by Compromise in Eleventh Century North-Western France, to be published in 1979 in the American Journal of Legal History.

${ }^{73}$ M. Gluckman, Custom and Conflict in Africa 1, 5 (1955). 
tian rather than Germanic? I think that it is still Germanic; warfare still holds a prime place in western society: it is still a way of life as much as a means of survival or expansion. ${ }^{76}$

Similarly, with regard to criminal law, property law, and even matrimonial law, the ties of kinship continued to predominate and continued to be ultimately enforced by blood-feud and composition. The Church preached marriage by consent of the spouses, but parents continued to have their children married in the cradle. The Church desacralized nature and made it a sin to practice magic or be superstitious, but Germanic man continued to believe in demons and powers in rocks and trees and to practice his magic and superstitions. Indeed, the Church eventually assimilated many of the pagan superstitions and-especially in the law-clothed them with Christian formulae and rituals.

\section{The Relation of Germanic Folklaw to Other Non-Western TYPES OF LAW}

If we view the folklaw of the peoples of northern and western Europe, say, in the year 1000 A.D. from the perspective of a century or a century-and-a-half later, we are struck by its primitive character. In the year 1000 there was no professional legal scholarship. There was no class of trained lawyers acting as judges, advocates, or advisers in ecclesiastical, royal, city, manorial, mercantile, or other courts. There was no concept of law as a body of principles, a corpus juris, in which diverse and contradictory customs and laws are reconciled. There were no textbooks on law and no professors to gloss them. There was no concept of law as an object of study distinct from theology and philosophy; indeed, theology and philosophy were themselves not yet conceived as distinct scholarly disciplines.

Moreover, seen from the perspective of the twelfth and thirteenth centuries, the institutions of legislation and adjudication of the peoples of northern and western Europe in the year 1000 were very rudimentary. Although kings issued laws, they did so only rarely, and largely in order to reaffirm or revise pre-existing customs. The law-making authority of popes, metropolitans, and bishops was also largely restricted to occasional reaffirmance or revision of preexisting rules laid down in Scripture by the Church Fathers or by Church councils. There was no idea that royal or ecclesiastical authorities had the task of systematically developing a body of sta-

"J. Wallace-HadRILL, supra note 41, at 151. 
tutory law. The so-called "codes," whether of "worldly law" or of "God's law," were, as we have seen, incomplete collections of specific customs, or specific rules, elliptical in character, without definitions of principles or concepts. Similarly, with regard to adjudication, there were no professional courts, that is, courts staffed with professional judges, and no idea that cases should be decided according to a system of general principles. There were, of course, established rules and procedures for punishing offenses, for compensating for harm, for enforcing agreements, for distributing property on death, and for dealing with many other problems related to justice. Each of the peoples of Europe had its own rather complex legal order. But none had a legal system, in the sense of a consciously articulated and systematized structure of legal institutions clearly differentiated from other social institutions and cultivated by a corps of persons specially trained for that task.

Not only the style of the early European folklaw but also its content seems primitive, "barbaric," by standards of the Western legal tradition that has developed since the eleventh and twelfth centuries-and indeed it was expressly condemned as barbaric by later jurists. In the twelfth century and thereafter, the earlier "magical-mechanical" modes of proof by ordeal and compurgation and battle were finally denounced and replaced. Kinship responsibility and self-enforcing local and feudal customs gave way to more "rational" standards of procedural and substantive law. The Church's law of penance, as manifested in the Penitentials of the sixth to tenth centuries, also seemed primitive to the canon lawyers of the eleventh and twelfth centuries, and they subjected it to farreaching changes.

Yet if we adopt a different and broader perspective-not the perspective of the Western legal tradition as it later developed, but the perspective of the legal concepts and institutions of nonWestern cultures-we are struck less by the negative features of the earlier folklaw than by its positive features. As in many nonWestern cultures, the basic law of the peoples of Europe from the sixth to the tenth centuries was not a body of rules imposed from on high but rather an integral part of the common consciousness, the "common conscience," of the community. The people themselves, in their public assemblies, legislated and judged; and when kings asserted their authority over the law it was chiefly to guide the custom and the legal consciousness of the people, not to re-make it. The bonds of kinship, of lordship units, and of territorial communities were the law. If those bonds were violated, the initial response was to seek vengeance, but vengeance was supposed to give way-and usually did-to negotiation for pecuniary sanctions and 
to reconciliation. Adjudication was often a stage in the reconciliation process. And so peace, once disrupted, was to be restored ultimately by diplomacy. Beyond the question of right and wrong was the question of reconciliation of the warring factions. The same can be said of the law of many contemporary so-called "primitive" societies of Africa, Asia, and South America, as well as of many ancient civilizations both of the past and of the present.

Without the professionalization and systematization of law, more scope could be left for people's attitudes and beliefs, and for their unconscious ideas, their processes of mythical thought. This gave rise to legal procedures that depended heavily on ritual and symbol, and in that sense were highly technical, but the substantive law was plastic and largely non-technical. Rights and duties were not bound to the letter of legal texts but were instead a reflection of community values: it was a living law that sprang, in Fritz Kern's words, "out of the creative wells of the sub-conscious." nizes that the customary law of this early period of European history was often "vague, confused, and impractical, technically clumsy," but it was also "creative, sublime, and suited to human needs." These characterizations, too, are applicable to the legal concepts and processes of many contemporary non-literate cultures of Africa, Asia, and South America as well as to complex, literate, ancient civilizations such as those of China, Japan, and India.

Thus characteristics of the folklaw of the Germanic and other peoples of Europe in the sixth to tenth centuries that from a Western point of view appear to be weaknesses may from a non-Western point of view appear to be strengths. The absence of law reform movements, of sophisticated legal machinery, of a strong central lawmaking authority, of a strong central judicial authority, of a body of law independent of religious beliefs and emotions, of a systematic legal science-are only one side of the coin. The other side is the presence of a sense of the wholeness of life and of the interrelatedness of law with all other aspects of life, a sense that legal institutions and legal processes as well as legal norms and legal decisions are all integrated in the harmony of the universe. Law, like art and myth and religion, like language itself, was for the peoples of Europe, in the early stages of their history, not primarily a matter of making and applying rules in order to determine guilt and fix judgment, not an instrument for the separation of people from each

\footnotetext{
$n$ F. KERN, supra note 37, at 179.

${ }^{78}$ Id. at 180. Kern speaks of "medieval" law, but he is clearly referring to the folklaw of the "early" Middle Ages.
} 
other on the basis of a set of principles, but rather a matter of holding people together, a matter of reconciliation. Law was conceived primarily as a mediating process, a mode of communication, rather than primarily as a process of rule-making and decisionmaking.

In these respects, Germanic and other European folklaw had much in common with certain Eastern legal philosophies. In the Sufi tradition of the Middle East, one of the stories told of the Mulla Nasrudin depicts him as a magistrate hearing his first case. The plaintiff argues so persuasively that Nasrudin exclaims, "I believe that you are right." The clerk of the court begs him to restrain himself, since the defendant is yet to be heard. Listening to the defendant's argument, Nasrudin is again so carried away that he cries out, "I believe you are right." The clerk of the court cannot allow this. "Your honor," he says, "they cannot both be right." "I believe you are right," Nasrudin replies. ${ }^{79}$ Both are right, yet both cannot be right. The answer is not to be found by asking the question: who is right? The answer is to be found by saving the honor of both sides and thereby restoring the right relationship between them.

In the tradition of peoples of Asia who have lived under the strong influence of both Buddhist and Confucian thought, social control is not to be found primarily in the allocation of rights and duties through a system of general norms but rather in the maintenance of right relationships among family members, among families within lordship units, and among families and lordship units within local communities all subject to the emperor. Social harmony is more important than "giving to each his due." Indeed, "each" is not conceived of as a being distinct from his society-or from the universe-but rather as an integral part of a system of social relationships subject to the Principle of Heaven. Therefore, in the ancient civilizations of Asia the traditional, collective, and intuitive sides of life were emphasized, and the intellectual, analytical, and legal sides were fused with and subordinated to them. ${ }^{80}$

73 The story is told in I. Shah, The Pleasantries of the Incredible Mulla Nasrudin 67 (1968). The same story is told in the Hebrew rabbinical tradition.

so On the intuitive (including mystical and poetic) and the analytical as two complementary aspects of consciousness, and their relationship to the two hemispheres of the brain and two sides of the body, see R. ORnstein, The Psychology of Consciousness 68-72 (1972), (quoting extensively from J. BRUNer, ON KNowing: Essays for the LefT HaNd 2-5 (1962)). Bruner relates the symbolism of the right hand to action, law, and science, and the symbolism of the left hand to sentiment, intuition, and heart. He notices the connection between the word for law in French-droit-and the word for the direction "right." (The same is true of the German word Recht, the Russian word pravo, and, for that matter, the English word 
This was true also of the peoples of Europe in the period with which we have been concerned-before the great explosion of the late eleventh and twelfth centuries. The folk myths that dominated their thought prior to-and after-the introduction of Christianity did not make a sharp division between magic and logic or between Fate and the rules of criminal law. Nor did Christianity-an Eastern religion-make a sharp division between faith and reason.

Some writers have argued that law cannot exist in a society whose social order reflects the "Eastern" concept of the fusion and harmony of all aspects of social life. Can we say, for example, that law exists among the Tiv of northern Nigeria, who have a system of social control that rests on clan and lineage loyalties, on clan reprisals, and on ritual reparation to avoid punishment by supernatural sources, but who have no distinct governmental institutions, no courts, and no word in their language for law? ?I $^{\text {TI }}$ They accept certain rules as binding upon them, certain decisions as authoritative, and certain procedures for declaring these rules and decisions as effective. Does the fact that they do not distinguish these procedures, decisions, and rules from religion, politics, economics, and other aspects of social life, and do not call them "law," mean that we should not call them that? May we not say that among the Tiv-and in many other societies-what we call law is wholly diffuse, wholly interwoven with religious, political, economic, family, and other social institutions and processes? A. S. Diamond, who defines law as rules of conduct whose breach is regularly met by sanctions imposed by the community through regular procedures, states categor-' ically that "the Tiv have no law."82 For Diamond, with his Western orientation, "law in the full sense of that word" consists of "rules of conduct enforceable by an organ of the state"; 83 this would also almost rule out Germanic law, which Diamond indeed considers to be only "near the beginnings of law." 84

\footnotetext{
"right," which once meant law in the large sense, as in the old expression "common Right," and which still means a legally protected claim, as in a "property right" or a "contract right.") Bruner understands however that scientific knowledge-and presumably law as well-cannot be reached only with the right hand. He writes in his Introduction:

Since childhood, I have been enchanted by the fact and the symbolism of the right hand and the left-the one the doer, the other the dreamer. The right is order and lawfulness, le droit. Its beauties are those of geometry and taut implication. Reaching for knowledge with the right hand is science. Yet to say only that much of science is to overlook one of its excitements, for the great hypotheses of science are gifts carried in the left.
}

J. BRUNER, supra, at 2.

st See P. Bohannan, Justice and Judgment Among the Tiv (1957).

"2 A. Diamond, supra note 6, at 317 n.10.

${ }^{23}$ Id. at 61 .

" Id. at $195,320$. 
The paradigm of a social order in which law is largely diffuse, largely interwoven with religious, political, economic, family, and other social institutions and processes was set forth more than a century ago in the writings of Sir Henry Maine, who advanced the thesis that such a social order preceded, historically, the development of the legal systems of Western Civilization. Maine wrote that the ancient Roman, Greek, and Hindu law codes, both in the East and the West "mingled up religious, civil, and merely moral ordinances, without any regard to differences in their essential character," and that "the severance of law from morality, and religion from law, [belong only] to the later stages of mental progress." To answer these statements, as Diamond does, by asserting that the early codes contain very little "religious matter," that they are "entirely secular," and that they "show no confusion between law and religion"86 begs the question of what is law and what is religion. Maine argued, in effect, that rules that might appear to a modern observer to be "entirely secular"-for example, that one who slays a freeman should pay 100 shillings wergeld and one who slays a nobleman should pay 300 shillings wergeld-were in fact wholly bound up with the moral and religious rules of the society. It is not sufficient to say that such a rule is to be distinguished from modern legal rules only insofar as there was an absence of centralized government or other specific "legal machinery" for enforcing it (as Dennis Lloyd has argued) ${ }^{87}$ or that the mode of enforcement of the

2s See H. Maine, Ancient Law: Its Connection with the EARLy History of Society and ITs Relation to Modern IdeAs 16 (10th ed. 1884).

* A. Diamond, supra note 6, at 47. Diamond also criticizes Maine for stating that the early codes "were mere collections of existing customs," $i d$. at 45 , and that in general "law is derived from pre-existing rules of conduct which are at the same time legal, moral, and religious in nature," id. at vii, (quoting H. MAINE, supra note 64, at 7). Indeed, Diamond considers the latter proposition to be so discredited that criticism of it is "hardly necessary in these days." Id. But Maine is almost always much more careful in his statements than his critics recognize. In the first place, he was speaking not of the Germanic codes but of the ancient Roman, Greek, and Hindu codes (the Twelve Tables, the Attic Code of Solon, the Law of Menu). In the second place, the proposition that historically "law" (note that here Maine does not say "codes") is "derived from" pre-existing rules of conduct is self-evident, unless one is to assume that the earliest legal rules sprang full-blown from the head of some lawmaker. That those pre-existing rules of conduct were moral and religious as well as legal in nature is what Diamond considers absurd; however, his argument is based on a confusion of "moral and religious" with "priestly" or "ecclesiastical." See notes 87 and 88 infra.

${ }^{87}$ D. LloYd, The IDEA OF LAW 231-32 (rev. ed. 1970). Lloyd writes:

At one time the view commonly held was that in early society it was impossible to differentiate between legal, moral and religious norms, since these were so closely interwoven into a single texture. . . . The fact, however, that customary observances may draw upon the religious beliefs of the community and obtain from them a good deal of their binding quality, does not mean, as was supposed by earlier writers such as Sir Henry Maine, that it is not possible to distinguish between religious and secular rules 
in a primitive society. . . [R]ules which constitute religious taboos of the community, violation of which will draw upon the offender direct punishment at the hands of the supernatural powers, are often distinguished from rules which regulate the social and economic organization of the community and whose enforcement is in the hands either of some secular authority - the tribe or clan itself, the chieftain, or group of elders-or the next-of-kin of an injured person.

However, the reference to Maine is misplaced since Maine never wrote that it is not possible in early societies to distinguish religious taboos enforceable by supernatural sanctions from rules of social and economic organization enforceable by the tribe or the kindred. What he wrote was that the "secular" rules (as Lloyd, Diamond, and others call them) drew-as Lloyd admits-upon the religious beliefs of the community and obtained from them a good deal of their binding quality; indeed, they were, in Lloyd's excellent phrase, "interwoven into a single texture."

The difference between Diamond and Maine, and to a lesser extent between Lloyd and Maine, arises less from a difference in identification of the salient facts than from a difference in concept of the nature and purpose of law. Both Diamond and Lloyd consider the hallmark of law to be the imposition by governmental officials of sanctions for breaches of rules. Thus Lloyd writes:

Broadly speaking ... the vital contrast between primitive custom and developed law is not that the former lacks the substantive features of law, or that it is unsupported by sanctions, but simply that there is an absence of centralized government. . . [ [T] are no centralized organs either for creating law or for enforcing it.

Id. at 235. Diamond's definition of law is also essentially positivist: law consists of rules laid down and enforced by the state. See note 86 supra. Maine, however, considers the essential feature of law to be the existence of a group of men-in effect, judges-who have "exclusive possession of the principles by which quarrels are decided." H. MaINE, supra note 85, at 12 . Maine was one of the first to show that a positivist definition of law will exclude much of primitive law from consideration, and that, on the other hand, a definition that embraces all custom, regardless of its source or nature, will leave virtually nothing out of consideration. Thus Maine, who in fact wrote little about Germanic folklaw, would probably have found its origin not primarily in the early codes, as Diamond does, but in the decisions - the dooms-of the folkmoots, which the codes reflected and guided. The rules of the Germanic codes, Maine would probably have said, were "derived from" pre-existing rules of conduct that were at the same time legal, moral, and religious in nature. What made the codes "law" was the fact that they consisted of judgments and dooms that reflected and guided the knowledge of those charged with declaring and applying custom in cases of conflict. However, as we have seen, the Frankish and Anglo-Saxon dooms were an integral part of a religious system-the system of wyrd and lof, and of ordeals and compurgation; they were not only "derived from" preexisting rules of conduct that were at the same time legal, moral, and religious in nature, but they were "interwoven" with moral and religious beliefs "into a single texture."

Because of his definition of law, Diamond is led to treat the Germanic codes as the law-instead of as a part of a larger legal (and, indeed, moral and religious) order. He goes so far as to argue that what was not in the codes could not have been important in the law, referring particularly to the fact that the early codes contained little on procedure. Thus he states that

to the barbarian of the day rules of law and not the procedure were the essence of the matter-a simple truth that might have appeared self-evident but for a widespread view of primitive law which well-known dicta of Maine have helped to spread-namely that to early man a rule of procedure predominates in importance over a rule of substance, so that substantive law has at first the look of being gradually secreted in the interstices of procedure ....

A. Diamond, supra note 6 , at 61 . The only basis for saying that the matter is "self-evident" is that there is little about procedure in the codes. However, the assumption that the codes were intended to deal with all important aspects of the law is wholly unfounded. They were chiefly intended to deal with those aspects of the law requiring a statement of substantive rules. The overwhelming majority of the provisions of the codes dealt with homicide, wounding, sexual offenses (rape, adultery, and seduction), and theft. Many things besides procedure 
rule (by ordeal or compurgation) was religious but the rule itself was secular (as Diamond would have it). ${ }^{88}$ The important point is that the whole Germanic system of rules of pecuniary compensation for injuries was part of the paradigm of wyrd and lof, wer and bot, mund, frith, borh, and wed-part of the system of fate and honor that fused law with religion, politics, economics, and clan and household loyalties. Diamond reduces his argument to absurdity when he contends that much of the Hebrew law of the Old Testament is also "secular law," wholly distinct from religion. The Hebrews never recognized such a distinction and would have denounced it; for them every word of the Bible was sacred.

My contention is that the folklaw of the peoples of Europe in the sixth to tenth centuries was merged with religion and morality, and yet it was law, a legal order, a legal dimension of social life; and further, that it makes sense to identify as a legal dimension of social life the shared sentiment of members of any community (even a family, neighborhood, or school) that they are bound by mutual rights and duties derived from an authority recognized by them. As soon as a child invokes principles of equality, consistency, and adherence to promise or rule to argue, for example, that he has a right to a certain toy, because his brother had it earlier and because they always take turns with it and because it is his and because his father said so, then it makes sense to speak of an appeal to Right or to Law. Such an argument may be discouraged by some systems of child rearing, especially those strongly influenced by the Confucian ethic. Yet that it has to be discouraged is some evidence that it is inherent in social ordering.

What needs to be said about a family-or a village-governed by the Confucian ethic is not that it has no law, but rather that the legal dimension of its life is wholly subordinated to the non-legal, the $f a$ to the $l i{ }^{89}$ What needs to be said about the Tiv is not that

were wholly omitted or hardly touched on. In some codes, treason, for example, was not covered. Feudal relations generally were omitted. Land law was hardly mentioned. The truth is that the formulation of substantive rules stating the precise amounts of money to be paid for various forms of injuries was an important part of the procedure of negotiating the settlement of inter-clan and inter-household conflict. Thus it can be said, with Maine, that the law of the codes does indeed have "the look of being secreted in the interstices of procedure."

${ }^{a x}$ Diamond states that law and religion have two points of contact in primitive societies: first, certain wrongs may be so abhorrent that they become both violations of law and breaches of religious norms, and second, religious sanctions or the belief in magic may be used in legal procedures to ascertain truth by the application of an ordeal or some other mode of divination. Otherwise, he says, the law is wholly secular and essentially unaffected by religion. A. Diamond, supra note 6, at 326. These conclusions follow, of course, from his definition of law. See notes 86 and 87 supra.

* See 1 \& 2 Fung Yu-Lan, A History Of Chinese Philospophy (D. Bodde trans. 1953). 
they have no law, but that their legal rights and duties are wholly interwoven with religious and other institutions and values. And what links the folklaw of the Germanic and other peoples of Europe in the fifth and sixth to the tenth and eleventh centuries to these and other non-Western legal orders is the fact that it was wholly subordinated to kinship, lordship, and kingship loyalties and wholly interwoven with the heroic struggle for honor in a universe ruled by Fate.

I have stressed the similarities between the Germanic folklaw and the so-called Archaic Law that characterized all Indo-European societies at some stage of their history. I have also stressed the similarities between the Germanic folklaw and the kinds of legal order found in many contemporary kinship societies as well as in other types of non-Western cultures. If a single phrase can be used to describe what all these various legal orders have in common, it is the sanctity of custom. Custom is sacred, in Sophocles' words, "because it is not of today or yesterday, but lives for ever, and none knows whence it sprang." 90 In this type of legal order, law is not considered to be something that is consciously and systematically and continuously made and remade by central authorities; there may be occasional legislation, but for the most part law is considered to be something that grows out of the patterns and norms of behavior, the folkways and the mores, of the community. Moreover, in this type of legal order custom is not subjected to conscious, systematic, and continuous rational scrutiny by jurists. Custom is so sacred that it might not even be called sacred: it is simply unquestioningly and unquestionably respected.

Yet the Germanic folklaw, that is, the folklaw of the peoples of northern and western Europe in the sixth to the tenth centuries, does not fit easily into the model or archetype of "Customary Law"-or, indeed, into any other model or archetype, including Archaic Law and primitive law-if only for the reason that it came

Heaven, that is, the natural universe, was said to interact with human affairs. Heaven determines the virtuous and punishes the wicked. Id. at 507. A good short summary of the meanings of $f a$ and $l i$ may be found in Bodde \& Morris, The Basic Concepts of Chinese Law in Traditional China 92, 99-108 (J. Liu \& W. Tu eds. 1970). The heavenly $l i$, rooted in innate human feeling, prescribe modes of behavior for the major human relationships of father and son, ruler and subject, husband and wife, elder and younger brother, friend and friend, whereas $f a$ (law) obliterates relationships by imposing a forced uniformity. The $l i$, created by the sages of antiquity in conformity with human nature and with cosmic order, have universal validity, whereas $f a$ is merely the ad hoc creation of modern men designed to enhance their political power. The rites and ceremonies of the $l i$ give poetry and beauty to life, whereas $f a$ is mechanistic and devoid of emotional content.

so Sophocles, Antigone, lines 454-57 (author's translation). 
under the influence of Christianity. The emergence of Christianity and its spread across Europe is a unique event, which cannot be explained by any general social theory. As we have seen, Christianity contradicted the Germanic worldview by splitting life into two realms, the realm of God and the realm of the world; it thereby challenged the ultimate sanctity of custom, including the ultimate sanctity of kinship, lordship, and kingship relations. It also challenged the ultimate sanctity of nature-of the water and fire of the ordeals, for example. It challenged their ultimate sanctity, however, without denying their sanctity altogether; on the contrary, the Church actually supported the sacred institutions and values of the folk (including the ordeals). The Church supported them and at the same time challenged them by setting up a higher alternative: the realm of God, God's law, the life of the world to come. Life was split into two realms, the eternal and the temporal. The temporal was thereby depreciated in value but not otherwise directly affected. The split took place not in the life of society but in the human soul. Yet social life was indirectly affected in important ways. The basic structure of the folklaw remained unaltered, but, as we have seen, many of its particular features were strongly influenced by Christian beliefs.

If we could subtract all traces of Christianity, the European folklaw of the sixth to tenth centuries might well fall into one or more of the models or archetypes of legal orders that have been offered by social theorists. It would fall squarely into Archaic Law, together with the Roman law in the time of the Twelve Tables, early Hindu law, ancient Greek law, and others. It would fall less squarely into primitive law. It might conceivably be viewed as a type of law characteristic of the transition from kinship society to feudalism. It would surely be an example of Customary Law in the sense described above-that is, of a legal order dominated by the sanctity of custom. But it is a serious mistake, though unfortunately a very common one, to discuss the legal institutions of the Frankish, Anglo-Saxon, and other peoples of Europe in the sixth to tenth centuries without making any reference to the Penitentials, or to the religious laws issued by kings, or to the central role of the clergy in all phases of government. The result is to underestimate the dynamic elements of Germanic law and also its strong moral components. Above all, Christianity attached a positive value to law that contrasts sharply with attitudes toward law characteristic of religions or philosophies of other societies whose general institutional structure is comparable to that of the Christianized peoples of Europe in the sixth to tenth centuries. On the other hand, if one compares the Church in the Germanic-Frankish period of European 
history with the Mosaic priesthood in the tribal period of the history of Israel, one is struck by the ambivalence of the Church's attitude toward law and by its other-worldliness. In fact, it was an essential part of the Christian faith of that time to deny the value of attempting to reform in any fundamental way the law of this world. The world's law was the law of a fallen creation. God's law alone could save the wicked from hell-fire.

It was this attitude toward law, and toward the relation of the Church to the world, that changed dramatically in the late eleventh and twelfth centuries. The Church set out to reform both itself and the world by law. It established itself as a visible, corporate, legal entity, independent of imperial, royal, feudal, and urban authorities. Autonomous bodies of law were articulated, first within the ecclesiastical polity and then within the various secular polities, in part to maintain the cohesion of each polity, in part to achieve the reform of each, in part to keep an equilibrium among them all. These new developments were only possible, however, because the foundations for them had been laid in the earlier period. It was then that a basis was established for the formation of stable communities; that basis was the integrated populus Christianus in which there was neither a separation of Church from State nor a separation of law from other modes of social control. From a sociological and historical point of view, the existence of such an integrated society was a necessary prerequisite to the later creation of diverse, autonomous, competing systems of law, ecclesiastical and secular. Without that prior integration, new legal systems would have been seen as merely mechanical and bureaucratic, and would have been incapable of achieving their ultimate purposes of cohesion, reform, and equilibrium.

In our own time the pre-history of the Western legal tradition in the Germanic folklaw takes on special significance. Western society during the past two generations has been characterized increasingly by fundamental divisions of race, of class, of the sexes, and of the generations. Also, bonds of faith have grown weak and bonds of kinship and of soil have given way to vague and abstract nationalisms. With the breakdown of stable communities, Western Man no longer has confidence in law as a way of protecting spiritual values against corrupting social, economic, and political forces. There is, of course, no returning to the past-least of all, to the remote beginnings of our civilization. Yet it is important, in a time of skepticism, for the skeptics, above all, to ask by what historical route we have come to our present predicament, and to confront 
their own nostalgia for an earlier age when people really believed that "peace vanquishes law, and love vanquishes justice."

" See note 74 supra. 